\title{
DFT Calculations and ROESY NMR Data for the Diastereochemical Characterization of Cytotoxic Tetraterpenoids from the Oleoresin of Abies balsamea
}

Serge Lavoie, ${ }^{\dagger, \S}$ Charles Gauthier, ${ }^{\dagger}, \ldots, \S$ Vakhtang Mshvildadze, ${ }^{\dagger}$ Jean Legault,${ }^{\dagger}$ Benoit Roger,${ }^{\dagger}$ and André Pichette ${ }^{*} \dagger$

†Université du Québec à Chicoutimi, Chaire de Recherche sur les Agents Anticancéreux d'Origine Naturelle, Laboratoire LASEVE, Département des Sciences Fondamentales, 555 boul. de l’Université, Chicoutimi (Québec), Canada, G7H 2B1

Hniversité de Poitiers, Institut de Chimie IC2MP, CNRS-UMR 7285, Équipe Synthèse Organique, 4 rue Michel Brunet, 86073 Poitiers Cedex 9, France

$\S$ Authors with equal contributions 
ABSTRACT: Eight non-carotenoid tetraterpenoids, abibalsamins C-J (3-10), were isolated from the oleoresin of Abies balsamea. Their chemical structures were determined based on analysis of 1D/2D NMR and MS data. The assignment of their relative configurations was accomplished using homonuclear coupling constants in tandem with ROESY data. However, the presence of two stereogenic centers on a flexible side chain complicated the characterization. In silico models and ROESY data were analyzed in order to assign relative configurations of the isolated tetraterpenoids. Abibalsamins $\mathrm{B}$ and $\mathrm{H}-\mathrm{J}$ showed moderate cytotoxicity against human A549 lung carcinoma cells with $\mathrm{IC}_{50}$ values ranging between 6.7 and $10 \mu \mathrm{M}$. 
Firs (genus Abies) are large evergreen conifers mainly found in temperate and boreal regions of the northern hemisphere. ${ }^{1}$ The first phytochemical investigation of Abies plants was reported 75 years ago by Takahashi. ${ }^{2}$ More than 900 secondary metabolites of diverse chemical structures have since been identified and some have demonstrated potent biological and pharmacological properties, such as antimicrobial, anti-inflammatory, and anticancer activities. ${ }^{3}$

The balsam fir (Abies balsamea L. Mill), a favorite Christmas tree in Canada, has been traditionally used by the Aboriginal peoples of North America as an antiseptic, and for treatment of tuberculosis and venereal diseases. ${ }^{4}$ The sticky oleoresin produced by the firs has been used to treat bruises, burns, colds, fractures, and sores. ${ }^{5}$ The traditional medicinal uses of $A$. balsamea have prompted the search for bioactive compounds from this tree. Phytochemical studies of balsam fir extracts led to the identification of secondary metabolites such as monoterpenoids, ${ }^{6-15}$ sesquiterpenoids, ${ }^{6-9,11,13,15-19}$ diterpenoids, ${ }^{20-22}$ and triterpenoids, ${ }^{22,23}$ as well as phenolic compounds $^{15}$ and ionones. ${ }^{24}$

In the course of implementing research aimed at identification of biologically active compounds from the vegetal species of the forests of Quebec, we have become interested in studying the phytochemical content of balsam fir. This investigation has resulted in the discovery of cytotoxic and antibacterial sesquiterpenoids found in its essential oil. ${ }^{6,8}$ The oleoresin was also investigated, leading to the isolation of new seco-lanostane and cycloartane-type triterpenoids such as abiesonic acid, (24E)-23-oxo-3,4-seco-9 $\beta H$-lanosta-4(28),7,24-triene-3,26-dioic acid and trans-sibiric acid. ${ }^{22}$ 

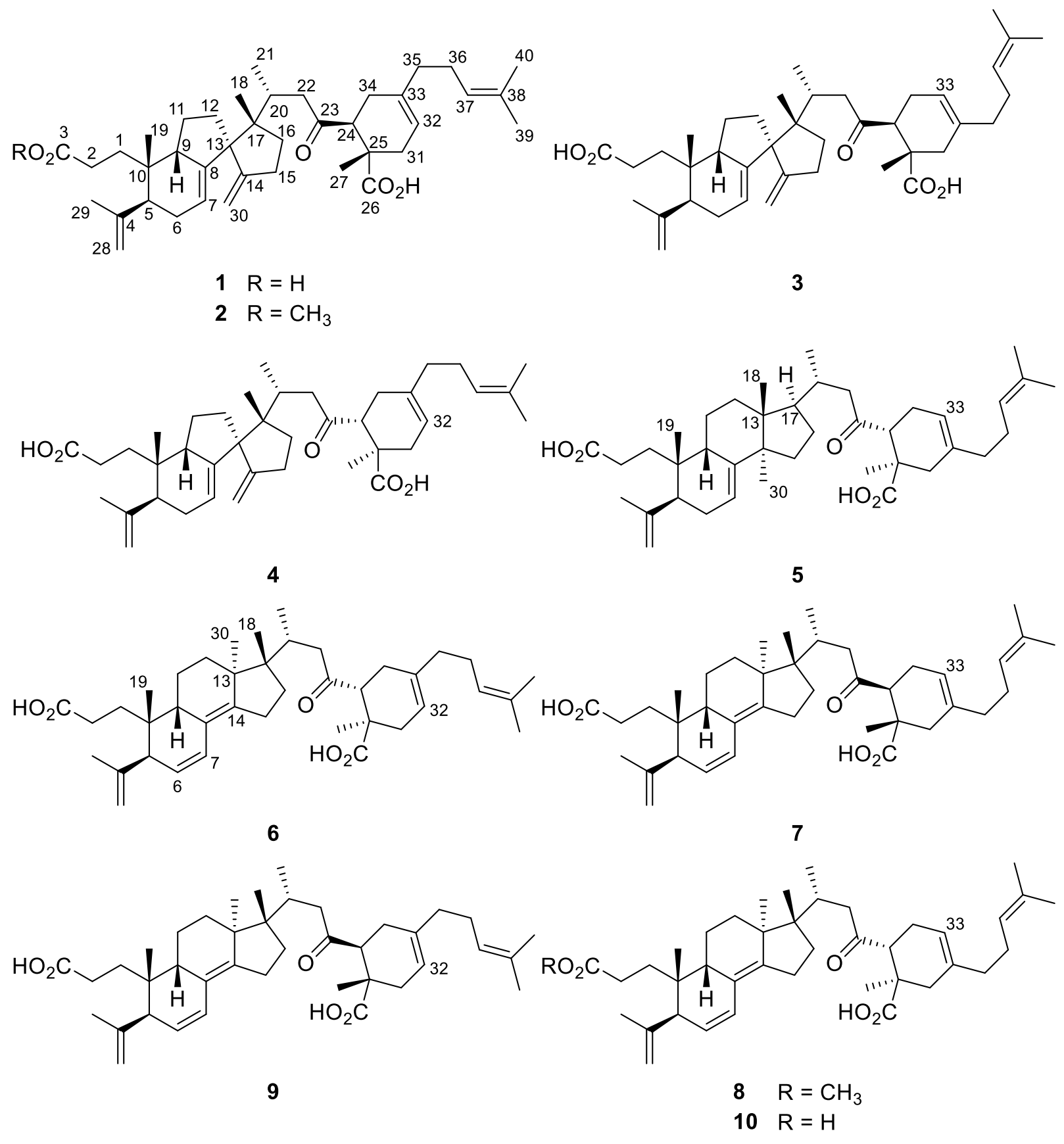

Additionally, we also isolated two non-carotenoid tetraterpenoids featuring 3,4-seco-rearranged lanostane units fused with masked $\beta$-myrcene moieties from the oleoresin of $A$. balsamea. ${ }^{23}$ These compounds, named abibalsamins A (1) and B (2), were proposed to be formed via a [4+2] Diels-Alder cycloaddition reaction, presumably catalyzed by a naturally occurring Diels- 
Alderase. The absolute configuration of abibalsamin A (1) was assigned by single-crystal X-ray diffraction. In the same year, $\mathrm{Li}$ and co-workers reported the isolation of two related tetraterpenoidal Diels-Alder adducts, abiestetranes A and B, from the aerial parts of $A$. fabri, a fir species endemic to China. ${ }^{25}$ The authors proposed a similar biosynthetic pathway for these compounds comprising a $[4+2]$ cycloaddition between $\beta$-myrcene and neoabiestrine $\mathrm{F}^{26}$ Importantly, abibalsamins A (1) and B (2), ${ }^{23}$ as well as abiestetranes A and $\mathrm{B},{ }^{25}$ were shown to exhibit potent cytotoxic activity against cancer cell lines.

A continuing phytochemical investigation of $A$. balsamea led to the isolation of eight tetraterpenoids similar to the aforementioned 3,4-seco-rearranged lanostanes. Having previously isolated their possible dienophile congeners, the discovery of these tetraterpenoids was expected. However, their absolute configurations were undefined due to difficulties obtaining single crystals suitable for X-ray analysis. Herein, the structural characterization of these compounds, named abibalsamins C-J (3-10), employing theoretical calculations, electronic circular dichroism, and ROESY NMR techniques are reported. The cytotoxicity of the isolated compounds against A549 and DLD-1 cancer cell lines is also discussed.

\section{RESULTS AND DISCUSSION}

Isolation of Abibalsamins $\mathbf{C}-\mathbf{J}$. The oleoresin of $A$. balsamea was subjected to silica gel column chromatography to remove nonpolar compounds. A series of fractionation steps, mainly consisting of column chromatographies on silica gel, were conducted leading to a fraction enriched with high molecular weight compounds. Semi-preparative HPLC purification permitted the isolation of eight (3-10) pure compounds. 
Structural Elucidation of Abibalsamins C-J. Compound 3 was obtained as a white amorphous powder. Based on the protonated molecular ion at $m / z 619.4351[\mathrm{M}+\mathrm{H}]^{+}$, and the ${ }^{13} \mathrm{C} \mathrm{NMR}$ data, the molecular formula of 3 was determined to be $\mathrm{C}_{40} \mathrm{H}_{58} \mathrm{O}_{5}$. A strong infrared absorption band at $1706 \mathrm{~cm}^{-1}$ corresponded to a carbonyl group. Analysis of the ${ }^{13} \mathrm{C}$ (Table 1), DEPT-135 and HSQC NMR data indicated that 3 possessed seven methyls, $12 s p^{3}$ methylenes, four $s p^{3}$ methines, four $s p^{3}$ quaternary carbons, two $s p^{2}$ methylenes, three $s p^{2}$ methines, five $s p^{2}$ quaternary carbons, and three carbonyl carbons. Analysis of the 2D NMR data (COSY, HSQC and $\mathrm{HMBC}$ ) indicated that abibalsamin C (3) was comprised of the same 3,4-seco-lanostane skeleton as abibalsamins A (1) and B (2). ${ }^{23}$ Furthermore, the structural moiety comprising a sixmembered ring and an isohexenyl group was identified, the location of the latter was determined to be at C-32 based on a COSY correlation between H-34 and H-24 (Figure 1). Abibalsamin C (3) was thus considered as a regioisomer of abibalsamin A (1).

The relative configuration of $\mathbf{3}$ was established by a ROESY experiment. Firstly, $\mathrm{H}_{3}-19$, H-9, and the C-5 isopropyl group were $\beta$-oriented based on ROESY correlations between $\mathrm{H}_{3}-19 / \mathrm{H}_{3}-29, \mathrm{H}_{3}$ 19/ $\mathrm{H}_{2}-28$ and $\mathrm{H}_{3}-19 / \mathrm{H}-9$ (Figure 1). The C-13 spiro configuration was proposed to be $R^{*}$ from a ROESY correlation between the pro- $\mathrm{Z} \mathrm{H}-30$ and $\mathrm{H}_{2}-1$ since the latter was below the ring plane. Thus, $\mathrm{H}_{3}-18$ was $\beta$-oriented based on a ROESY correlation between $\mathrm{H}_{3}-18$ and H-7. A ROESY correlation between $\mathrm{H}-24$ and $\mathrm{H}_{2}-28$ allowed the placement of the cyclohexyl moiety above the core tricyclic system. This arrangement was confirmed by X-ray diffraction crystallography of abibalsamin A (1). The relative configuration of C-20 was assigned as $R^{*}$ based on the fact that all cycloartane and lanostane triterpenoids isolated from Abies spp. until now showed the same configuration. ${ }^{27,28}$ The $J_{\mathrm{H}-24, \mathrm{H}-34 \mathrm{ax}}(11.9 \mathrm{~Hz})$ and $J_{\mathrm{H}-24, \mathrm{H}-34 \mathrm{eq}}(5.2 \mathrm{~Hz})$ coupling constants suggested an axial orientation for $\mathrm{H}-24$ (Table 2$)$. Also, the relatively small chemical shift value of C-27 $\left(\delta_{\mathrm{C}}\right.$ 
16.2) could be attributed to an axial methyl (Table 1). Indeed, the NMR spectroscopic data of both epimers of similar structural arrangements, a cyclohexene moiety substituted with a hydroxycarbonyl and a methyl group, were reported. ${ }^{29-31}$ Owing to the flexibility of the lateral chain, the configuration of the C-24 and C-25 stereocenters could not be related to the configuration of the core skeleton of the molecule. Therefore, abibalsamin C (3) was provisionally identified as 24,25-[3-(4-methylpent-3-enyl)but-2-ene-1,4-diyl]-23-oxo-3,4-seco17,13-friedo-8(14 $\rightarrow 13)$ abeo-9 $\beta \mathrm{H}$-lanosta-4(28),7,14(30)-triene-3,26-dioic acid.

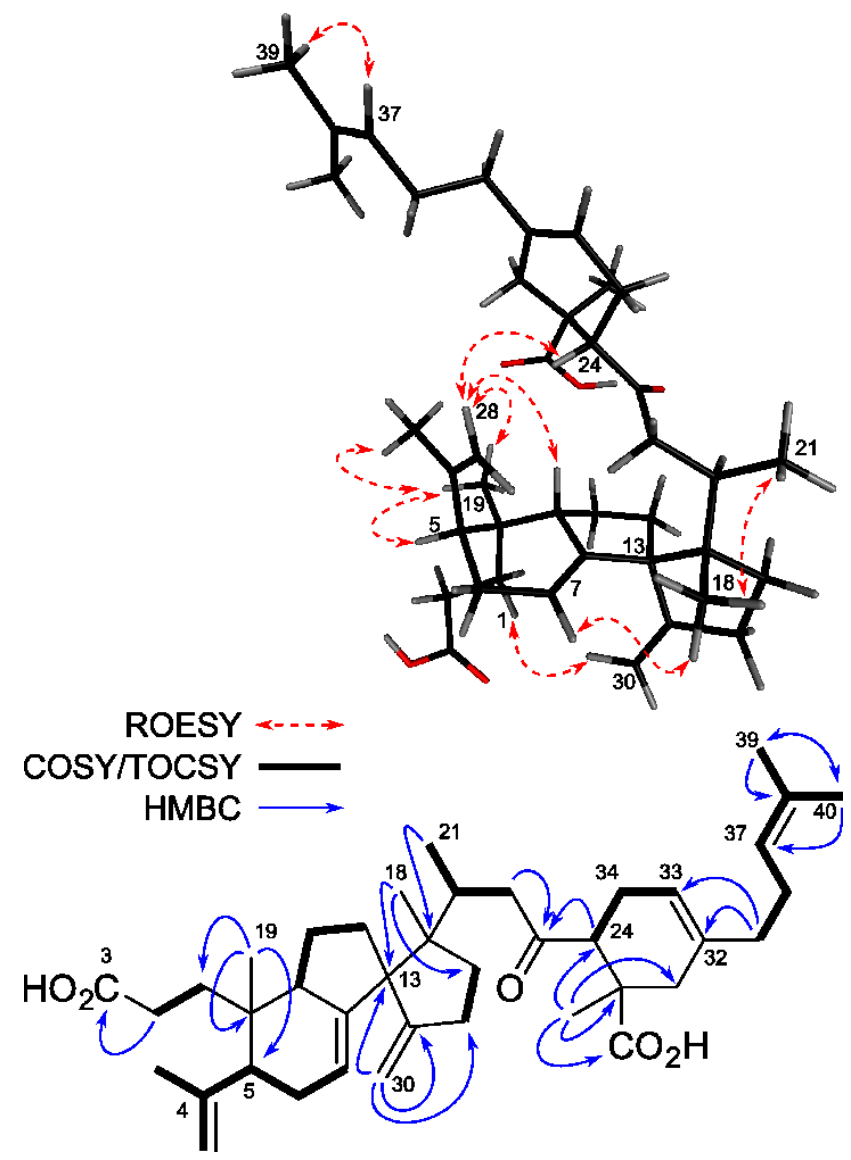

Figure 1. Key ${ }^{1} \mathrm{H}-{ }^{1} \mathrm{H}$ COSY, HMBC, and ROESY correlations of abibalsamin C (3) 
Table $1 .{ }^{13} \mathrm{C}$ NMR Spectroscopic Data (100 $\left.\mathrm{MHz}, \mathrm{CDCl}_{3}\right)$ for Compounds 3-10 ( $\delta$ in ppm)

\begin{tabular}{|c|c|c|c|c|c|c|c|c|}
\hline position & 3 & 4 & 5 & 6 & 7 & 8 & 9 & 10 \\
\hline 1 & 30.5 & 30.3 & 28.7 & 28.9 & 29.0 & 28.6 & 28.6 & 28.5 \\
\hline 2 & 29.3 & 29.3 & 29.2 & 30.2 & 30.3 & 29.8 & 29.9 & 29.9 \\
\hline 3 & 179.9 & 180.2 & 181.0 & 181.4 & 181.5 & 174.9 & 180.7 & 180.9 \\
\hline 4 & 149.3 & 149.5 & 149.7 & 145.8 & 145.8 & 145.9 & 145.8 & 145.8 \\
\hline 5 & 44.0 & 43.9 & 45.3 & 50.6 & 50.6 & 50.6 & 50.6 & 50.5 \\
\hline 6 & 30.9 & 31.0 & 29.7 & 126.5 & 126.5 & 126.7 & 126.6 & 126.6 \\
\hline 7 & 122.0 & 122.1 & 117.8 & 125.3 & 125.3 & 125.3 & 125.3 & 125.3 \\
\hline 8 & 143.9 & 143.8 & 146.4 & 125.0 & 124.9 & 125.1 & 125.0 & 125.0 \\
\hline 9 & 49.3 & 49.2 & 38.6 & 39.5 & 39.5 & 39.6 & 39.4 & 39.5 \\
\hline 10 & 36.9 & 36.8 & 36.2 & 37.1 & 37.2 & 37.1 & 37.1 & 37.1 \\
\hline 11 & 22.7 & 22.7 & 18.5 & 19.8 & 19.8 & 19.8 & 19.7 & 19.8 \\
\hline 12 & 31.2 & 31.2 & 33.8 & 32.2 & 32.2 & 32.4 & 32.2 & 32.3 \\
\hline 13 & 63.5 & 63.5 & 43.7 & 47.4 & 47.4 & 47.4 & 47.4 & 47.4 \\
\hline 14 & 161.4 & 161.5 & 51.6 & 146.8 & 146.9 & 146.6 & 146.7 & 146.7 \\
\hline 15 & 28.0 & 28.0 & 33.9 & 23.9 & 23.9 & 23.9 & 23.9 & 23.9 \\
\hline 16 & 36.0 & 36.2 & 28.2 & 35.9 & 35.9 & 35.9 & 35.9 & 35.9 \\
\hline 17 & 50.3 & 50.3 & 53.3 & 48.7 & 48.7 & 48.7 & 48.9 & 48.8 \\
\hline 18 & 18.0 & 18.0 & 21.6 & 16.2 & 16.2 & 16.2 & 16.1 & 16.2 \\
\hline 19 & 24.7 & 24.6 & 24.1 & 21.9 & 21.9 & 21.9 & 21.9 & 21.9 \\
\hline 20 & 34.7 & 34.8 & 32.2 & 32.5 & 32.7 & 33.5 & 34.1 & 33.8 \\
\hline 21 & 16.3 & 16.2 & 19.8 & 17.0 & 16.9 & 16.5 & 16.6 & 16.6 \\
\hline 22 & 45.4 & 45.5 & 49.4 & 45.6 & 45.1 & 44.8 & 45.0 & 44.8 \\
\hline 23 & 213.1 & 213.0 & 212.1 & 211.7 & 211.5 & 211.6 & 211.8 & 211.7 \\
\hline 24 & 51.5 & 51.8 & 50.3 & 50.7 & 50.5 & 51.6 & 52.0 & 51.7 \\
\hline 25 & 43.4 & 43.0 & 43.2 & 43.0 & 43.3 & $43.0^{a}$ & 42.6 & 43.0 \\
\hline 26 & 183.5 & 183.9 & 184.3 & 184.7 & 184.7 & $183.1^{a}$ & 184.2 & 184.3 \\
\hline 27 & 16.2 & 15.9 & 15.8 & 15.8 & 15.9 & 16.0 & 15.6 & 15.8 \\
\hline 28 & 112.1 & 111.9 & 112.0 & 115.5 & 115.5 & 115.4 & 115.5 & 115.5 \\
\hline 29 & 26.3 & 26.5 & 26.0 & 24.8 & 24.8 & 24.8 & 24.8 & 24.8 \\
\hline 30 & 106.6 & 106.8 & 27.5 & 22.0 & 22.0 & 21.9 & 21.8 & 21.9 \\
\hline 31 & 40.3 & 37.5 & 40.5 & 37.8 & 40.7 & 40.5 & 37.6 & 40.5 \\
\hline 32 & 135.6 & 118.2 & 135.6 & 118.4 & 135.7 & 135.8 & 118.4 & 135.8 \\
\hline 33 & 118.3 & 135.6 & 118.3 & 135.7 & 118.3 & 118.1 & 135.5 & 118.2 \\
\hline 34 & 25.6 & 28.7 & 25.5 & 28.5 & 25.6 & 25.5 & 28.4 & 25.4 \\
\hline 35 & 37.4 & 37.1 & 37.3 & 37.0 & 37.3 & 37.3 & 37.0 & 37.3 \\
\hline 36 & 26.3 & 26.3 & 26.3 & 26.3 & 26.3 & 26.3 & 26.3 & 26.3 \\
\hline 37 & 123.8 & 123.8 & 123.8 & 123.8 & 123.8 & 123.8 & 123.8 & 123.8 \\
\hline 38 & 131.8 & 131.9 & 131.8 & 131.8 & 131.8 & 131.8 & 131.8 & 131.8 \\
\hline 39 & 25.7 & 25.7 & 25.7 & 25.7 & 25.7 & 25.7 & 25.7 & 25.7 \\
\hline 40 & 17.8 & 17.7 & 17.8 & 17.7 & 17.8 & 17.8 & 17.8 & 17.8 \\
\hline $\mathrm{OMe}$ & - & - & - & - & - & 51.6 & - & - \\
\hline
\end{tabular}

${ }^{a}$ Deduced from the HMBC spectrum. 
Table 2. ${ }^{1} \mathrm{H}$ NMR Spectroscopic Data (400 $\left.\mathrm{MHz}, \mathrm{CDCl}_{3}\right)$ for Compounds 3-6 ( $\delta$ in ppm, $J$ in Hz)

\begin{tabular}{|c|c|c|c|c|}
\hline position & 3 & 4 & 5 & $\overline{6}$ \\
\hline \multirow[t]{2}{*}{1} & $1.74 \mathrm{~m}$ & $1.73 \mathrm{~m}$ & $1.72 \mathrm{~m}$ & $1.59 \mathrm{~m}$ \\
\hline & $1.63 \mathrm{~m}$ & $1.64 \mathrm{~m}$ & $1.57 \mathrm{~m}$ & \\
\hline 2 & $2.32 \mathrm{~m}$ & $2.32 \mathrm{~m}$ & $2.30 \mathrm{~m}$ & $2.24 \mathrm{~m}$ \\
\hline 5 & $2.07 \mathrm{~m}$ & $2.07 \mathrm{~m}$ & $2.07 \mathrm{~m}$ & $2.63 \mathrm{~d}(5.5)$ \\
\hline \multirow[t]{2}{*}{6} & $2.39 \mathrm{~m}$ & $2.39 \mathrm{~m}$ & $2.26 \mathrm{~m}$ & $5.37 \mathrm{~m}$ \\
\hline & $2.14 \mathrm{~m}$ & $2.14 \mathrm{~m}$ & $1.98 \mathrm{~m}$ & \\
\hline 7 & 5.44 br s & 5.45 br s & 5.31 br s & $6.23 \mathrm{~d}(9.9)$ \\
\hline 9 & $2.09 \mathrm{~m}$ & $2.10 \mathrm{~m}$ & $2.57 \mathrm{~m}$ & $2.40 \mathrm{~m}$ \\
\hline \multirow[t]{2}{*}{11} & $1.59 \mathrm{~m}$ & $1.59 \mathrm{~m}$ & $1.63 \mathrm{~m}$ & $1.58 \mathrm{~m}$ \\
\hline & $1.40 \mathrm{~m}$ & $1.41 \mathrm{~m}$ & $1.53 \mathrm{~m}$ & \\
\hline \multirow[t]{2}{*}{12} & $1.78 \mathrm{~m}$ & $1.78 \mathrm{~m}$ & $1.81 \mathrm{~m}$ & $1.59 \mathrm{~m}$ \\
\hline & $1.31 \mathrm{~m}$ & & $1.64 \mathrm{~m}$ & \\
\hline \multirow[t]{2}{*}{15} & $2.45 \mathrm{~m}$ & $2.45 \mathrm{~m}$ & $1.52 \mathrm{~m}$ & $2.34 \mathrm{~m}$ \\
\hline & $2.35 \mathrm{~m}$ & $2.35 \mathrm{~m}$ & $1.44 \mathrm{~m}$ & \\
\hline \multirow[t]{2}{*}{16} & $1.54 \mathrm{~m}$ & $1.53 \mathrm{~m}$ & $1.87 \mathrm{~m}$ & $1.73 \mathrm{~m}$ \\
\hline & & & $1.23 \mathrm{~m}$ & $1.47 \mathrm{~m}$ \\
\hline 17 & & & $1.47 \mathrm{~m}$ & \\
\hline 18 & $0.87 \mathrm{~s}$ & $0.89 \mathrm{~s}$ & $0.78 \mathrm{~s}$ & $0.68 \mathrm{~s}$ \\
\hline 19 & $0.93 \mathrm{~s}$ & $0.92 \mathrm{~s}$ & $0.84 \mathrm{~s}$ & $0.84 \mathrm{~s}$ \\
\hline 20 & $2.30 \mathrm{~m}$ & $2.31 \mathrm{~m}$ & $2.04 \mathrm{~m}$ & $2.39 \mathrm{~m}$ \\
\hline 21 & $0.80 \mathrm{~d}(5.2)$ & $0.80 \mathrm{~d}(5.1)$ & $0.84 \mathrm{~d}(6.4)$ & $0.80 \mathrm{~d}(6.6)$ \\
\hline \multirow[t]{2}{*}{22} & $2.31 \mathrm{~m}$ & $2.33 \mathrm{~m}$ & $2.56 \mathrm{~m}$ & $2.72 \mathrm{~d}(17.2)$ \\
\hline & $2.18 \mathrm{~m}$ & $2.17 \mathrm{~m}$ & $2.20 \mathrm{~m}$ & $2.28 \mathrm{~m}$ \\
\hline 24 & $2.92 \mathrm{dd}(11.9,5.2)$ & $2.98 \mathrm{dd}(11.6,5.0)$ & $3.02 \mathrm{dd}(12.0,5.4)$ & $3.03 \mathrm{dd}(12.4,5.2)$ \\
\hline 27 & $1.26 \mathrm{~s}$ & $1.25 \mathrm{~s}$ & $1.25 \mathrm{~s}$ & $1.29 \mathrm{~s}$ \\
\hline \multirow[t]{2}{*}{28} & $4.81 \mathrm{~s}$ & $4.81 \mathrm{~s}$ & $4.88 \mathrm{~s}$ & $4.97 \mathrm{~s}$ \\
\hline & & & $4.81 \mathrm{~s}$ & $4.76 \mathrm{~s}$ \\
\hline 29 & $1.76 \mathrm{~s}$ & $1.76 \mathrm{~s}$ & $1.79 \mathrm{~s}$ & $1.78 \mathrm{~s}$ \\
\hline \multirow[t]{2}{*}{30} & $4.74 \mathrm{~s}$ & $4.75 \mathrm{~s}$ & $1.03 \mathrm{~s}$ & $1.00 \mathrm{~s}$ \\
\hline & $4.70 \mathrm{~s}$ & $4.70 \mathrm{~s}$ & & \\
\hline \multirow[t]{2}{*}{31} & $2.37 \mathrm{~m}$ & $2.39 \mathrm{~m}$ & $2.36 \mathrm{~m}$ & $2.36 \mathrm{~m}$ \\
\hline & $1.93 \mathrm{~m}$ & $2.02 \mathrm{~m}$ & $1.93 \mathrm{~m}$ & $2.03 \mathrm{~m}$ \\
\hline 32 & & 5.37 br s & & $5.36 \mathrm{~m}$ \\
\hline 33 & 5.40 br s & & 5.41 br s & \\
\hline \multirow[t]{2}{*}{34} & $2.35 \mathrm{~m}$ & $2.16 \mathrm{~m}$ & $2.39 \mathrm{~m}$ & $2.20 \mathrm{~m}$ \\
\hline & $1.97 \mathrm{~m}$ & $1.96 \mathrm{~m}$ & $2.02 \mathrm{~m}$ & $1.95 \mathrm{~m}$ \\
\hline 35 & $1.98 \mathrm{~m}$ & $2.01 \mathrm{~m}$ & $1.99 \mathrm{~m}$ & $2.03 \mathrm{~m}$ \\
\hline 36 & $2.06 \mathrm{~m}$ & $2.08 \mathrm{~m}$ & $2.06 \mathrm{~m}$ & $2.09 \mathrm{~m}$ \\
\hline 37 & $5.07 \mathrm{t}(6.9)$ & $5.07 \mathrm{t}(6.9)$ & $5.07 \mathrm{t}(6.9)$ & $5.07 \mathrm{t}(6.9)$ \\
\hline 39 & $1.68 \mathrm{~s}$ & $1.68 \mathrm{~s}$ & $1.68 \mathrm{~s}$ & $1.68 \mathrm{~s}$ \\
\hline 40 & $1.60 \mathrm{~s}$ & $1.60 \mathrm{~s}$ & $1.60 \mathrm{~s}$ & $1.61 \mathrm{~s}$ \\
\hline
\end{tabular}


Compound 4 was obtained as a white amorphous powder, with its molecular formula determined as $\mathrm{C}_{40} \mathrm{H}_{58} \mathrm{O}_{5}$ based on an HRESIMS protonated molecular ion at $\mathrm{m} / \mathrm{z} 619.4349$. The infrared spectrum of 4 showed a strong absorption band at $1707 \mathrm{~cm}^{-1}$, suggesting the presence of a carbonyl functionality. The ${ }^{1} \mathrm{H}$ and ${ }^{13} \mathrm{C}$ NMR spectra of compounds $\mathbf{1}$ and $\mathbf{4}$ displayed significant similarities. Indeed, a COSY correlation was observed between $\mathrm{H}-32$ and $\mathrm{H}-31$, indicating that the isohexenyl side-chain was located at C-33, as for abibalsamin A (1) (Figure 2). The ROESY correlations of $\mathbf{4}$ were similar to those of $\mathbf{1}$, suggesting that the relative configurations of the core skeleton of these molecules were also the same. Furthermore, both the Me-27 and H-24 were axially oriented based on the coupling pattern of $\mathrm{H}-24(\mathrm{dd}, J=11.6,5.0 \mathrm{~Hz})$ with $\mathrm{H}_{2}-34$ and a ROESY correlation between $\mathrm{H}_{3}-27$ and $\mathrm{H}-34_{\text {ax }}$. Nevertheless, compounds $\mathbf{4}$ and $\mathbf{1}$ could not be considered as enantiomers since they were isolated from the same HPLC run and had slightly different NMR spectroscopic data (see Figures S57-S58 and Tables S1-S3, Supporting Information). This led to the postulation that $\mathbf{4}$ was a diastereoisomer of $\mathbf{1}$, an unsurprising result if one assumes that the abibalsamins are biosynthesized via a Diels-Alder reaction. ${ }^{23,25}$ Indeed, Diels-Alder cycloadditions are well-known to produce diastereoisomeric products. ${ }^{32}$ Thus, abibalsamin D (4) was identified as 24R,25R-[2-(4-methylpent-3-enyl)but-2-ene-1,4-diyl]-23oxo-3,4-seco-17,13-friedo-8(14 $\rightarrow 13)$ abeo-9 $\beta$ H-lanosta-4(28),7,14(30)-triene-3,26-dioic acid. 


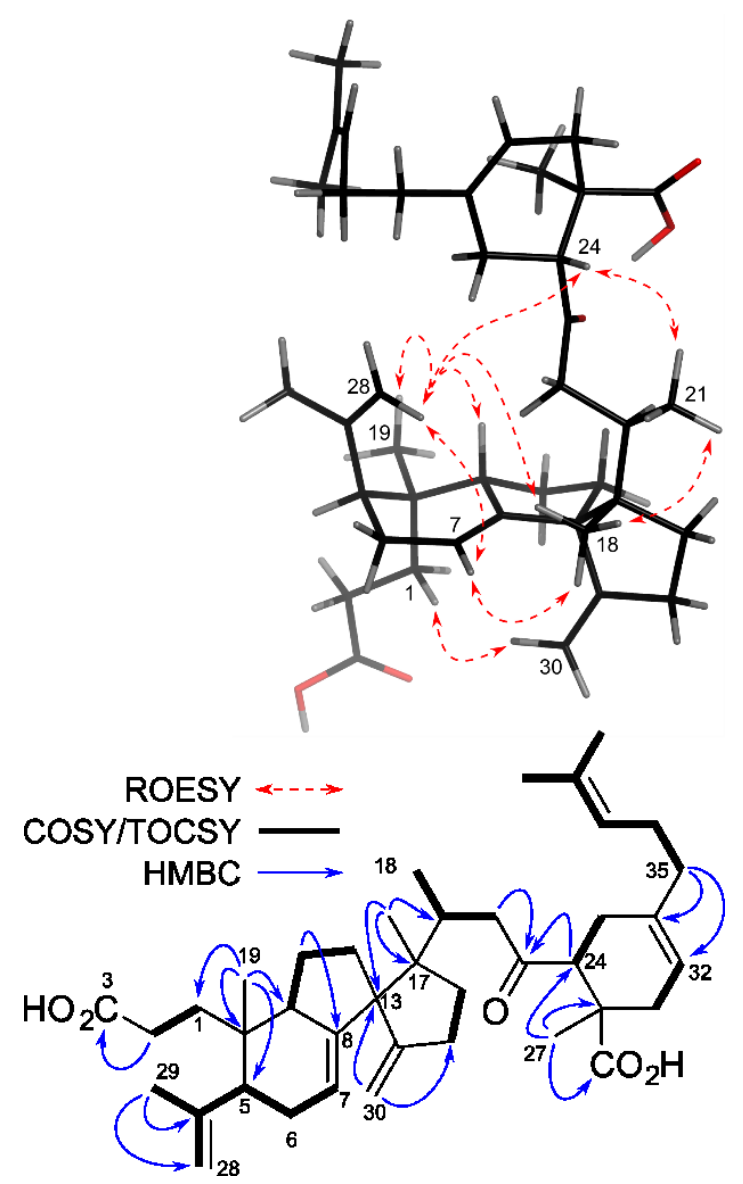

Figure 2. Key ${ }^{1} \mathrm{H}-{ }^{1} \mathrm{H}$ COSY, HMBC, and ROESY correlations of abibalsamin D (4)

The molecular formula of compound 5 was deduced to be $\mathrm{C}_{40} \mathrm{H}_{60} \mathrm{O}_{5}$ from an HRESIMS protonated molecular ion at $m / z 621.4508[\mathrm{M}+\mathrm{H}]^{+}$. A carbonyl group was inferred from the strong infrared band at $1705 \mathrm{~cm}^{-1}$. Analysis of the ${ }^{13} \mathrm{C}$, DEPT and HSQC NMR spectra revealed the presence of eight methyls, $12 s p^{3}$ methylenes, five $s p^{3}$ methines, four $s p^{3}$ quaternary carbons, one $s p^{2}$ methylene, three $s p^{2}$ methines, four $s p^{2}$ quaternary carbons, and three carbonyl carbons (Table 1). Examination of the HSQC, COSY and HMBC spectra of 5 identified the same core skeleton as (24E)-3,4-seco-9 $\beta$ H-lanosta-4(28),7,24-triene-3,26-dioic acid. ${ }^{33}$ Indeed, a double bond could be assigned at C-7 based on the COSY correlations between $\mathrm{H}_{2}-6$ and $\mathrm{H}-7$, as well as 
the $\mathrm{HMBC}$ correlation between $\mathrm{H}_{3}-30$ and $\mathrm{C}-8$ (Figure 3). Furthermore, the C-23 structural moiety was identical to that of abibalsamin C (3) with the isohexenyl group located at C-32 based on the COSY correlations between $\mathrm{H}-33$ and $\mathrm{H}_{2}-34$. The relative configuration of 5 was determined from a ROESY experiment (Figure 3). Firstly, correlations from the pro- $Z \mathrm{H}-28$ to $\mathrm{H}_{3}-19$ and $\mathrm{H}_{3}-18$ suggested that all these groups were $\beta$-oriented. ROESY correlations between $\mathrm{H}_{3}-18 / \mathrm{H}-9, \mathrm{H}_{3}-30 / \mathrm{H}-17$, and $\mathrm{H}_{3}-18 / \mathrm{H}-16 \beta$ permitted the determination of the orientation of $\mathrm{H}-9$ and of the C-17 substituent to be $\beta$. Finally, Me-30 was shown to be $\alpha$-oriented from the ROESY correlation with $\mathrm{H}-16 \alpha$. The scalar coupling of $\mathrm{H}-24$ with $\mathrm{H}_{2}-34$ (dd, $J=11.9,5.4 \mathrm{~Hz}$ ), along with the small chemical shift value of C-27 $\left(\delta_{\mathrm{C}} 15.8\right)$, led to the same conclusion as for compound $\mathbf{3}$, i.e. these two groups were axially oriented. Furthermore, $\mathrm{H}_{3}-27$ could be unambiguously correlated to H-34 $4_{\mathrm{ax}}$ via the ROESY spectrum, which further confirmed the axial position of the methyl group. Owing to these spectroscopic evidence (Tables 1 and 2), abibalsamin E (5) was tentatively identified as 24,25-[3-(4-methylpent-3-enyl)but-2-ene-1,4diyl]-23-oxo-3,4-seco-9 $\beta$ H-lanosta-4(28),7-diene-3,26-dioic acid. 


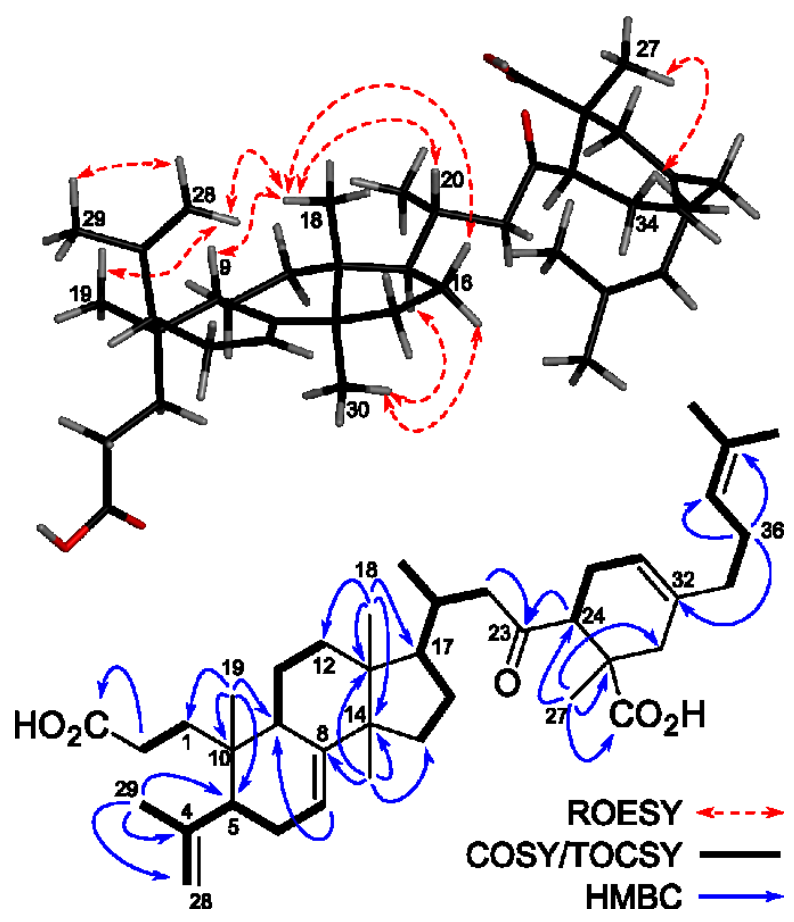

Figure 3. Key ${ }^{1} \mathrm{H}-{ }^{1} \mathrm{H}$ COSY, HMBC, and ROESY correlations of abibalsamin E (5)

Compound 6 showed a protonated molecular ion at $m / z 619.4346[\mathrm{M}+\mathrm{H}]^{+}$in the HRESIMS data, indicating a molecular formula of $\mathrm{C}_{40} \mathrm{H}_{58} \mathrm{O}_{5}$. The presence of a carbonyl group could be deduced from a strong infrared band at $1704 \mathrm{~cm}^{-1}$. The ${ }^{13} \mathrm{C}$ and DEPT NMR spectra confirmed the presence of eight methyls, $11 s p^{3}$ methylenes, four $s p^{3}$ methines, four $s p^{3}$ quaternary carbons, one $s p^{2}$ methylene, four $s p^{2}$ methines, five $s p^{2}$ quaternary carbons, and three carbonyl carbons. Examination of the 2D spectra (HSQC, COSY and HMBC) indicated that 6 had a 3,4-secolanostane skeleton similar to that of trans-sibiric acid. ${ }^{22}$ Conjugated olefinic bonds were assigned at C-6 and C-8(14) from the COSY correlations between H-5/H-6 and H-6/H-7, and from the HMBC correlations between $\mathrm{H}_{3}-30$ and $\mathrm{C}-14$ and from $\mathrm{H}-7$ to C-6, C-8, and C-14 (Figure 4). The C-23 structural moiety was identical to that of abibalsamin A (1), i.e. with the isohexenyl unit at C-33 of a six-membered ring. 
The stereochemical features of the tetraterpenoid $\mathbf{6}$ were investigated using a ROESY experiment (Figure 4). ROESY correlations from the pro- $\mathrm{Z} \mathrm{H}-28$ to $\mathrm{H}-9$ and $\mathrm{H}_{3}-19$ indicated that the isopropylene functionality was cofacial with $\mathrm{H}-9$ and $\mathrm{H}_{3}-19$. The orientation of the $\mathrm{C}-18$ and $\mathrm{C}$ 30 methyl groups were determined to be opposite since the hydrogens of the former $\left(\mathrm{H}_{3}-18\right)$ correlated with $\mathrm{H}-16 \beta\left(\delta_{\mathrm{H}} 1.48\right)$ and those of the latter $\left(\mathrm{H}_{3}-30\right)$ with $\mathrm{H}-16 \alpha\left(\delta_{\mathrm{H}} 1.73\right)$. Owing to strong overlapping, neither $\mathrm{H}_{3}-18$ nor $\mathrm{H}_{3}-30$ could be related to the other stereocenters. However, comparison of their ${ }^{1} \mathrm{H}$ and ${ }^{13} \mathrm{C}$ NMR spectroscopic data (Tables 1 and 2) with those of transsibiric acid ${ }^{22}$ indicated a $\beta$ orientation for $\mathrm{H}_{3}-18$ and $\alpha$ for $\mathrm{H}_{3}-30$. Given the consistent biosynthetic pathways towards the core skeleton of abilalsamins, the relative configuration of compound $\mathbf{6}$ is presumably identical to those of the reported derivatives. Concerning the cyclohexene moiety, the configurations at C-24 and C-25 were shown to be the same as those of previous compounds, as evidenced by the coupling pattern of $\mathrm{H}-24$ with $\mathrm{H}_{2}-34$ (dd, $J=12.4,5.2$ $\mathrm{Hz}$ ) and by a ROESY correlation between $\mathrm{H}_{3}-27$ and $\mathrm{H}-34_{\mathrm{ax}}$. Consequently, abibalsamin F (6) was provisionally identified as 24,25-[2-(4-methylpent-3-enyl)but-2-ene-1,4-diyl]-23-oxo-3,4seco-9 $\beta$ H-lanosta-4(28),6,8(14)-triene-3,26-dioic acid. 



Figure 4. Key ${ }^{1} \mathrm{H}-{ }^{1} \mathrm{H}$ COSY, HMBC, and ROESY correlations of abibalsamin F (6)

A protonated molecular ion at $m / z 619.4350[\mathrm{M}+\mathrm{H}]^{+}$was observed in the HRESIMS of 7, suggesting a molecular formula of $\mathrm{C}_{40} \mathrm{H}_{58} \mathrm{O}_{5}$. The IR absorption band at $1704 \mathrm{~cm}^{-1}$ was assigned to a carbonyl group. From the ${ }^{13} \mathrm{C}$ and DEPT NMR data (Table 1), eight methyls, $11 s p^{3}$ methylenes, four $s p^{3}$ methines, four $s p^{3}$ quaternary carbons, one $s p^{2}$ methylene, four $s p^{2}$ methines, five $s p^{2}$ quaternary carbons, and three carbonyl carbons were deduced. Detailed examination of the 2D NMR spectra (COSY, HSQC, HMBC and ROESY) implied that 7 shared the same skeleton as compound $\mathbf{6}$, but possessed the same C-23 substituent as compounds $\mathbf{3}$ and $\mathbf{5}$. The COSY correlations between $\mathrm{H}-5 / \mathrm{H}-6$ and $\mathrm{H}-6 / \mathrm{H}-7$ along with the $\mathrm{HMBC}$ correlations from $\mathrm{H}_{3}-30$ to $\mathrm{C}-14$ and from $\mathrm{H}-7$ to $\mathrm{C}-6, \mathrm{C}-8$ and $\mathrm{C}-14$ permitted assignment of the conjugated olefinic bonds at C-6 and C-8(14). The same C-23 substituent as for compounds $\mathbf{3}$ and $\mathbf{5}$, i.e. with the isohexenyl group at C-32, was determined from COSY correlations between $\mathrm{H}-33$ and $\mathrm{H}_{2}-34$. 
Therefore, abibalsamin G (7) was provisionally identified as 24,25-[3-(4-methylpent-3-enyl)but2-ene-1,4-diyl]-23-oxo-3,4-seco-9 $\beta$ H-lanosta-4(28),6,8(14)-triene-3.26-dioic acid. 
Table 3. ${ }^{1} \mathrm{H}$ NMR Spectroscopic Data $\left(400 \mathrm{MHz}, \mathrm{CDCl}_{3}\right)$ for Compounds $7-10$ ( $\delta$ in ppm, $J$ in $\mathrm{Hz}$ )

\begin{tabular}{|c|c|c|c|c|}
\hline position & 7 & 8 & 9 & $\overline{10}$ \\
\hline 1 & $1.59 \mathrm{~m}$ & $1.59 \mathrm{~m}$ & $1.58 \mathrm{~m}$ & $1.58 \mathrm{~m}$ \\
\hline 2 & $2.24 \mathrm{~m}$ & $2.25 \mathrm{~m}$ & $2.27 \mathrm{~m}$ & $2.27 \mathrm{~m}$ \\
\hline 5 & $2.63 \mathrm{~m}$ & $2.63 \mathrm{~d}(5.6)$ & $2.62 \mathrm{~d}(5.4)$ & $2.62 \mathrm{~d}(5.4)$ \\
\hline 6 & $5.37 \mathrm{dd}(9.9,5.4)$ & $5.36 \mathrm{dd}(9.9,5.3)$ & $5.36 \mathrm{~m}$ & $5.36 \mathrm{dd}(9.9,5.4)$ \\
\hline 7 & $6.23 \mathrm{~d}(9.9)$ & $6.21 \mathrm{~d}(10.0)$ & $6.22 \mathrm{~d}(9.9)$ & $6.21 \mathrm{~d}(9.9)$ \\
\hline 9 & $2.40 \mathrm{~m}$ & $2.39 \mathrm{~m}$ & $2.40 \mathrm{~m}$ & $2.39 \mathrm{~m}$ \\
\hline 11 & $1.57 \mathrm{~m}$ & $1.59 \mathrm{~m}$ & $1.59 \mathrm{~m}$ & $\begin{array}{l}1.61 \mathrm{~m} \\
1.56 \mathrm{~m}\end{array}$ \\
\hline 12 & $1.58 \mathrm{~m}$ & $\begin{array}{l}1.62 \mathrm{~m} \\
1.53 \mathrm{~m}\end{array}$ & $\begin{array}{l}1.63 \mathrm{~m} \\
1.56 \mathrm{~m}\end{array}$ & $\begin{array}{l}1.63 \mathrm{~m} \\
1.54 \mathrm{~m}\end{array}$ \\
\hline 15 & $2.34 \mathrm{~m}$ & $\begin{array}{l}2.37 \mathrm{~m} \\
2.28 \mathrm{~m}\end{array}$ & $\begin{array}{l}2.37 \mathrm{~m} \\
2.30 \mathrm{~m}\end{array}$ & $\begin{array}{l}2.37 \mathrm{~m} \\
2.28 \mathrm{~m}\end{array}$ \\
\hline 16 & $\begin{array}{l}1.73 \mathrm{~m} \\
1.47 \mathrm{~m}\end{array}$ & $\begin{array}{l}1.71 \mathrm{~m} \\
1.47 \mathrm{~m}\end{array}$ & $\begin{array}{l}1.71 \mathrm{~m} \\
1.47 \mathrm{~m}\end{array}$ & $\begin{array}{l}1.71 \mathrm{~m} \\
1.47 \mathrm{~m}\end{array}$ \\
\hline 18 & $0.67 \mathrm{~s}$ & $0.67 \mathrm{~s}$ & $0.68 \mathrm{~s}$ & $0.67 \mathrm{~s}$ \\
\hline 19 & $0.84 \mathrm{~s}$ & $0.84 \mathrm{~m}$ & $0.85 \mathrm{~s}$ & $0.85 \mathrm{~m}$ \\
\hline 20 & $2.38 \mathrm{~m}$ & $2.36 \mathrm{~m}$ & $2.35 \mathrm{~m}$ & $2.35 \mathrm{~m}$ \\
\hline 21 & $0.79 \mathrm{~d}(6.2)$ & $0.80 \mathrm{~d}(6.0)$ & $0.81 \mathrm{~d}(6.1)$ & $0.80 \mathrm{~d}(6.1)$ \\
\hline 22 & $\begin{array}{l}2.66 \mathrm{~m} \\
2.28 \mathrm{~m}\end{array}$ & $\begin{array}{l}2.55 \mathrm{~m} \\
2.30 \mathrm{~m}\end{array}$ & $\begin{array}{l}2.52 \mathrm{~d}(14.4) \\
2.28 \mathrm{~m}\end{array}$ & $\begin{array}{l}2.52 \mathrm{~d}(14.7) \\
2.29 \mathrm{~m}\end{array}$ \\
\hline 24 & $2.99 \mathrm{dd}(12.2,5.4)$ & $3.00 \mathrm{dd}(11.9,5.4)$ & $3.09 \mathrm{dd}(12.0,5.3)$ & $3.01 \mathrm{dd}(11.9,5.5)$ \\
\hline 27 & $1.28 \mathrm{~s}$ & $1.26 \mathrm{~s}$ & $1.21 \mathrm{~s}$ & $1.23 \mathrm{~s}$ \\
\hline 28 & $\begin{array}{l}4.97 \mathrm{~s} \\
4.76 \mathrm{~s}\end{array}$ & $\begin{array}{l}4.96 \text { br s } \\
4.75 \text { br s }\end{array}$ & $\begin{array}{l}4.96 \text { br s } \\
4.76 \text { br s }\end{array}$ & $\begin{array}{l}4.96 \mathrm{~s} \\
4.75 \mathrm{~s}\end{array}$ \\
\hline 29 & $1.78 \mathrm{~s}$ & $1.78 \mathrm{~s}$ & $1.78 \mathrm{~s}$ & $1.78 \mathrm{~s}$ \\
\hline 30 & $1.00 \mathrm{~s}$ & $1.00 \mathrm{~s}$ & $1.05 \mathrm{~s}$ & $1.02 \mathrm{~s}$ \\
\hline 31 & $2.33 \mathrm{~m}$ & $2.35 \mathrm{~m}$ & $2.41 \mathrm{~m}$ & $2.36 \mathrm{~m}$ \\
\hline 32 & $1.93 \mathrm{~m}$ & $1.94 \mathrm{~m}$ & $\begin{array}{l}2.00 \mathrm{~m} \\
5.37 \mathrm{~m}\end{array}$ & $1.92 \mathrm{~m}$ \\
\hline 33 & 5.42 br s & 5.42 br s & & 5.42 br s \\
\hline 34 & $\begin{array}{l}2.41 \mathrm{~m} \\
1.99 \mathrm{~m}\end{array}$ & $2.43 \mathrm{~m}$ & $2.25 \mathrm{~m}$ & $2.44 \mathrm{~m}$ \\
\hline 35 & $\begin{array}{l}1.99 \mathrm{~m} \\
1.97 \mathrm{~m}\end{array}$ & $\begin{array}{l}2.03 \mathrm{~m} \\
2.04 \mathrm{~m} \\
1.98 \mathrm{~m}\end{array}$ & $\begin{array}{l}2.00 \mathrm{~m} \\
2.10 \mathrm{~m} \\
2.03 \mathrm{~m}\end{array}$ & $\begin{array}{l}2.03 \mathrm{~m} \\
1.97 \mathrm{~m}\end{array}$ \\
\hline 36 & $2.06 \mathrm{~m}$ & $2.07 \mathrm{~m}$ & $2.09 \mathrm{~m}$ & $2.06 \mathrm{~m}$ \\
\hline 37 & $5.06 \mathrm{t}(6.9)$ & $5.07 \mathrm{t}(7.2)$ & $5.08 \mathrm{t}(6.7)$ & $5.07 \mathrm{t}(7.0)$ \\
\hline 39 & $1.68 \mathrm{~s}$ & $1.68 \mathrm{~s}$ & $1.69 \mathrm{~s}$ & $1.68 \mathrm{~s}$ \\
\hline 40 & $1.60 \mathrm{~s}$ & $1.61 \mathrm{~s}$ & $1.61 \mathrm{~s}$ & $1.60 \mathrm{~s}$ \\
\hline $\mathrm{OMe}$ & & $3.65 \mathrm{~s}$ & & \\
\hline
\end{tabular}


Compound 8 exhibited a protonated molecular ion at $m / z 633.4516[\mathrm{M}+\mathrm{H}]^{+}$in HRESIMS which together with its ${ }^{13} \mathrm{C}$ NMR spectrum indicated a molecular formula of $\mathrm{C}_{41} \mathrm{H}_{60} \mathrm{O}_{5}$. The NMR data of 8 were similar to those of abibalsamin G (7), except for the presence of a methoxy group $\left(\delta_{\mathrm{C}}\right.$ $51.6, \delta_{\mathrm{H}} 3.65$ ), implying that 8 was a methyl ester derivative of 7 . This methyl ester functionality comprises C-3 based upon a shielded C-3 resonance $\left(\Delta \delta_{\mathrm{C}}=-6.5 \mathrm{ppm}\right.$, Table 1), along with an HMBC correlation between the methoxy protons and C-3. Abibalsamin $\mathrm{H}(\mathbf{8})$ was, therefore, temporarily assigned as the 3-methyl ester of 24,25-[3-(4-methylpent-3-enyl)but-2-ene-1,4-diyl]23-oxo-3,4-seco-9 $\beta$ H-lanosta-4(28),6,8(14)-triene-3,26-dioic acid.

The molecular formula of compounds $\mathbf{9}$ and $\mathbf{1 0}$, were both ascertained to be $\mathrm{C}_{40} \mathrm{H}_{58} \mathrm{O}_{5}$ from the HRESIMS protonated molecular ions at $m / z 619.4349$ and $619.4352[\mathrm{M}+\mathrm{H}]^{+}$, respectively. Examination of their NMR spectra, including COSY, HSQC, HMBC and ROESY, showed that 9 was a diastereoisomer of $\mathbf{6}$ and that $\mathbf{1 0}$ was a diastereoisomer of $\mathbf{7}$, much like the relationship of compound 4 with 1 . Indeed, both compounds were shown to possess conjugated olefinic bonds at C-6 and C-8(14) based on COSY correlations between H-5/H-6 and H-6/H-7 and HMBC correlations from $\mathrm{H}_{3}-30$ to $\mathrm{C}-14$ and from $\mathrm{H}-7$ to $\mathrm{C}-6, \mathrm{C}-8$ and $\mathrm{C}-14$. Also, the olefinic protons of the Diels-Alder generated cyclohexene moiety showed COSY correlations with $\mathrm{H}_{2}-31$ in the case of compound 9 and with $\mathrm{H}_{2}-34$ in the case of compound 10. This implied that the isohexenyl groups were connected to at C-33 and C-32 for 9 and 10, respectively. Finally, H-24 and the C-27 methyl group were axially oriented for both compounds, as demonstrated by the coupling pattern of $\mathrm{H}-24$ and the ROESY correlation of $\mathrm{H}_{3}-27$ and $\mathrm{H}-34_{\mathrm{ax}}$. 
Stereochemistry of Abibalsamins. Ten tetraterpenoids were isolated from the oleoresin of $A$. balsamea. Their structures led to the speculation that these compounds may be biosynthesized via the Diels-Alder addition between a $\beta$-myrcene moiety (diene) and one of the following triterpenoids (dienophile): abiesonic acid for compounds 1-4; $(24 E)-23$-oxo-3,4-seco-9 $\beta H$ lanosta-4(28),7,24-triene-3,26-dioic acid for compound 5; and trans-sibiric acid for compounds 6-10. When dealing with Diels-Alder adducts, four different isomers should be considered: ${ }^{34}$ two regioisomers (isohexenyl side-chain at either C-32 or C-33), as well as two diastereoisomers (configuration at C-24/C-25 either $S, S$ or $R, R)$. Interestingly, the four possible isomers $(\mathbf{6}, \mathbf{7}, \mathbf{9}$, and 10), as well as the methyl ester $\mathbf{8}$ of compound 10, have been isolated from the oleoresin of A. balsamea in the specific case of a Diels-Alder reaction with trans-sibiric acid as the dienophile. Therefore, computational molecular modeling was performed with tetraterpenoids 6 10. The three triterpenoid precursors were all characterized to be of $E$ geometry at C-24, ${ }^{22}$ which is consistent with the known orientation at these positions. For the molecular modeling, the stereogenic centers in the core skeleton were assumed as identified previously, i.e. $(5 S, 9 S, 10 S, 13 R, 17 S, 20 R)$ for derivatives of abiesonic acid (1-4), $(5 S, 9 S, 10 S, 13 R, 14 R, 17 R, 20 R)$ for the derivative of (24E)-23-oxo-3,4-seco-9 $\beta H$-lanosta-4(28),7,24-triene-3,26-dioic acid (5), and $(5 S, 9 S, 10 R, 13 S, 17 S, 20 R)$ for derivatives of trans-sibiric acid (6-10).

Importantly, the configurations at both C-24 and C-25 could not be related to the rest of the molecule because of the undefined position of the C-23 substituent. Therefore, in order to assign the absolute configuration of abiestetranes A and B, Li and co-workers compared the experimental electronic circular dichroism (ECD) spectra to those obtained from quantum mechanical computations. ${ }^{25}$ The same approach was followed for abibalsamins C-J (3-10). Firstly, eight models (I to VIII) representing all of the possible Diels-Alder isomers were 
generated using appropriate precursors, isohexenyl positions, and configurations at both the C-24 and C-25 stereogenic centers (Table 4). Since these models were conformationally flexible, a conformational analysis was undertaken using the molecular mechanics package of Spartan. An energy cut-off of $21 \mathrm{~kJ} \mathrm{~mol}^{-1}$ was chosen to investigate a large number of structures (Table S4, Supporting Information). Between 100 to 200 structures within an energy cut-off of $4-8 \mathrm{~kJ} \mathrm{~mol}^{-1}$, were geometrically optimized using DFT at the B3LYP/3-21G level. Calculation of frequencies for all conformers confirmed that all were true minimum (no imaginary frequency) and led to Gibbs free energies, which in turn were used to calculate the Boltzmann distribution at room temperature for each model (Tables S5-S6, Supporting Information). Conformers contributing over $2 \%$ in proportion of the population were selected for the computation of the ECD spectra at the B3LYP/3-21GG//B3LYP/3-21G level with the polarizable continuum model in MeOH. Each calculated spectrum was assigned a Boltzmann weight according to the free energy of the minimized conformers at 298.15 K (Figure S63, Supporting Information). Both the calculated and measured ECD spectra of the trans-sibiric acid Diels-Alder adducts (6-10) were significantly similar.

An important conclusion can be drawn from these results. Since the experimental ECD spectra of compounds 6-10 were similar, it was not possible to assign the relative configurations at the $\mathrm{C}$ 24/C-25 stereogenic centers. Nonetheless, Li and co-workers were unequivocal regarding the determination of the absolute configuration of abiestetranes. ${ }^{25}$ Since they did not take into account the other possible diastereoisomers in the calculations of their ECD spectra, as strongly recommended by Polavarapu, ${ }^{35}$ their results should be considered with caution. In addition, Polavarapu advised the use of more than one spectroscopic method to distinguish between 
stereoisomers. Therefore, the aforementioned calculated models were instead used to interpret the slight differences observed in the experimental ROESY NMR spectra of the abibalsamins.

Table 4. Characteristic of the Computational Models I-VIII

\begin{tabular}{|c|c|c|c|c|c|}
\hline Model & dienophile & isohexenyl & confi & ration & possible \\
\hline & precursor $^{a}$ & position & C-24 & $\mathrm{C}-25$ & compounds \\
\hline I & A & C-33 & $S$ & $S$ & 6,9 \\
\hline II & A & C-33 & $R$ & $R$ & 6,9 \\
\hline III & A & C-32 & $S$ & $S$ & $7, \mathbf{8}, 10$ \\
\hline IV & A & $\mathrm{C}-32$ & $R$ & $R$ & $7, \mathbf{8}, \mathbf{1 0}$ \\
\hline V & B & C-32 & $S$ & $S$ & 3 \\
\hline VI & B & $\mathrm{C}-32$ & $R$ & $R$ & 3 \\
\hline VII & $\mathrm{C}$ & C-32 & $S$ & $S$ & 5 \\
\hline VIII & $\mathrm{C}$ & C-32 & $R$ & $R$ & 5 \\
\hline
\end{tabular}

${ }^{a}$ Dienophile precusors are: $\mathrm{A}=$ trans-sibiric acid; $\mathrm{B}=$ abiesonic acid; $\mathrm{C}=(24 E)$-23-oxo-3,4seco-9 $\beta H$-lanosta-4(28),7,24-triene-3,26-dioic acid.

One of the most apparent differences in the ROESY NMR spectra of compounds 6 and 9 was the correlations between $\mathrm{H}-24$ and $\mathrm{H}_{3}-21$ (Figure 5). Indeed, a cross-peak was visible in the spectrum of 9, while the same cross-peak was barely visible for the tetraterpenoid 6. Distances were then evaluated from the in silico models and linked to these observations. Accordingly, values from all conformers were averaged with weight from the room temperature abundance according to a previously established equation. ${ }^{36}$ Based on these analyses, the methyl group $\mathrm{H}_{3}-21$ was 3.81 or $4.47 \AA$ apart from H-24 for models I and II, respectively. Since the intensity of the ROESY crosspeak is correlated to $r^{-6}$, it suggested that abibalsamin F (6) could be related to model II, while abibalsamin I (9) could be linked to model I. Therefore, both compounds were proposed to be 24R,25R-[2-(4-methylpent-3-enyl)but-2-ene-1,4-diyl]-23-oxo-3,4-seco-9 $\beta$ H-lanosta4(28),6,8(14)-triene-3,26-dioic acid (6) and 24S,25S-[2-(4-methylpent-3-enyl)but-2-ene-1,4diyl]-23-oxo-3,4-seco-9 $\beta$ H-lanosta-4(28),6,8(14)-triene-3,26-dioic acid (9). 

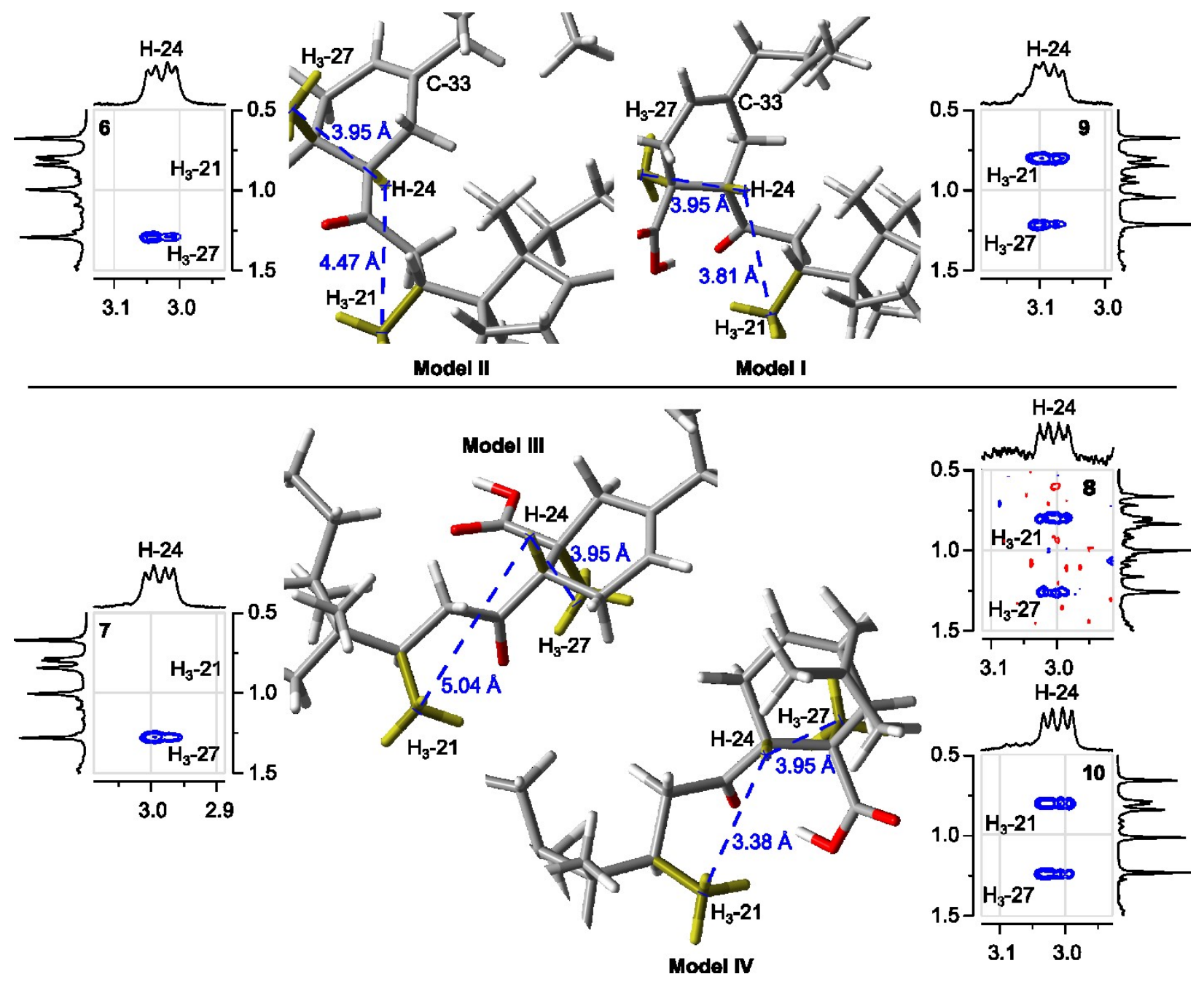

Figure 5. Linking of ROESY spectra for abibalsamins F-J (6-10) with calculated models I-IV

Following this protocol, four calculated models (V-VIII) were also developed for tetraterpenoids 3 or 5, and with configurations defined as $S, S$ or $R, R$ at C-24/C-25 (Table 4). Since the ECD spectra were shown not to be suitable for the determination of the absolute configuration of the C-24/C-25 stereogenic centers, they were neither recorded nor calculated in this case. The in silico models (Table S6, Supporting Information) were instead used to explain some important ROESY correlations, as previously described. For compound 3, a cross-peak was observed between $\mathrm{H}-24$ and $\mathrm{H}_{2}-28$ that was even stronger than the cross-peaks observed between $\mathrm{H}-24 / \mathrm{H}_{3}-$ 
21 and $\mathrm{H}-24 / \mathrm{H}_{3}-27$ (Figure 6). This correlation, observed in the ROESY NMR spectra of abibalsamins A and B (1-2), was explained using X-ray diffraction crystallography. ${ }^{23}$ The weighted mean distances were calculated from the two in silico models V and VI as 2.52 and 4.47 $\AA$, respectively. Model V, with its smaller distance, was established to be a better model to justify the strong observed correlation. Therefore, the structure of abibalsamin C (3) was proposed to be $24 S, 25 S$-[3-(4-methylpent-3-enyl)but-2-ene-1,4-diyl]-23-oxo-3,4-seco-17,13friedo-8(14 $\rightarrow 13$ )abeo-9 $\beta$ H-lanosta-4(28),7,14(30)-triene-3,26-dioic acid.
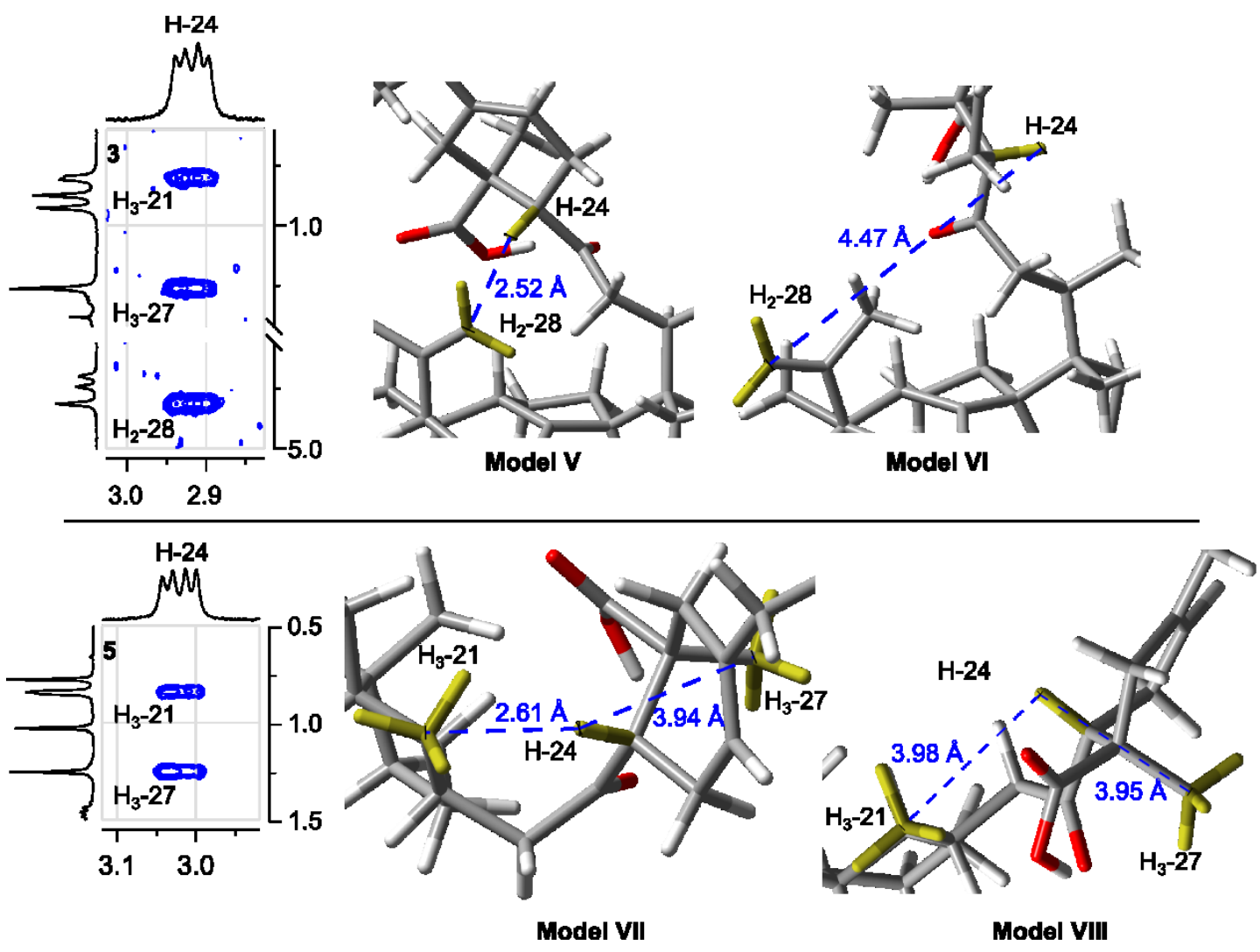

Figure 6. Linking of ROESY spectra for abibalsamins C (3) and E (5) with calculated models VVIII

For compound 5, the diagnostic correlations were those between $\mathrm{H}-24 / \mathrm{H}_{3}-21$ and $\mathrm{H}-24 / \mathrm{H}_{3}-27$. Indeed, the corresponding ROESY correlations were observed at the same intensity, implying 
that both methyls were equidistant from H-24 (Figure 6). The calculated model VIII showed distances of 3.98 and $3.95 \AA$, respectively, while model VII showed a shorter distance for H24/H 3 -21 (2.61 $\AA$ ). Therefore, the structure of abibalsamin E (5) was proposed to be $24 R, 25 R$-[3(4-methylpent-3-enyl)but-2-ene-1,4-diyl]-23-oxo-3,4-seco-9 $\beta \mathrm{H}-$ lanosta-4(28),7-diene-3,26-dioic acid.

Are Abibalsamins Artifacts? As previously stated, abibalsamins are likely formed via the $[4+2]$ Diels-Alder cycloaddition reaction between $\beta$-myrcene and dienophiles such as abiesonic acid, (24E)-23-oxo-3,4-seco-9 $\beta H$-lanosta-4(28),7,24-triene-3,26-dioic acid, as well as transsibiric acid. Since the latter compounds have been isolated from the oleoresin of $A$. balsamea, ${ }^{22}$ it is legitimate to ask whether abibalsamins are naturally occurring compounds or rather artifacts formed during the isolation process. ${ }^{37,38}$ Several facts point towards the artifactual character of abibalsamins: (1) the identification of regio- and diastereoisomeric mixtures, ${ }^{39}$ (2) the activated nature of the triterpenoid dienophiles that could enhance the reactivity of the Diels-Alder reaction; ${ }^{40}$ and (3) the isolation process involving the use of silica gel, which has been shown to be a good catalyst for Diels-Alder reactions when $\beta$-myrcene is employed as the diene. ${ }^{41}$ In order to provide evidence of abibalsamins being true natural products, a crude sample of oleoresin was methylated using diazomethane and analyzed by GC-MS. As revealed in Figure 7, approximately 10 late eluting peaks were detected in the chromatogram, generating mass signals greater than $m / z 600$. The mass spectra associated with these signals exhibited molecular ions at $m / z 646.5$, which was consistent with the exact mass of the fully methylated derivatives of abibalsamins. Therefore, the latter experiment validated the presence of abibalsamins in the oleoresin as naturally occurring compounds and not as isolation artifacts. We cannot rule out, however, that 
these Diels-Alder adducts would be formed in situ, under the action of sun-light on the oleoresin for instance, without the need for a Diels-Alderase. On the other hand, the recent isolation and characterization of some natural Diels-Alderases from plants have shown that these enzymes can indeed be involved in the biosynthesis of natural products. ${ }^{42,43}$
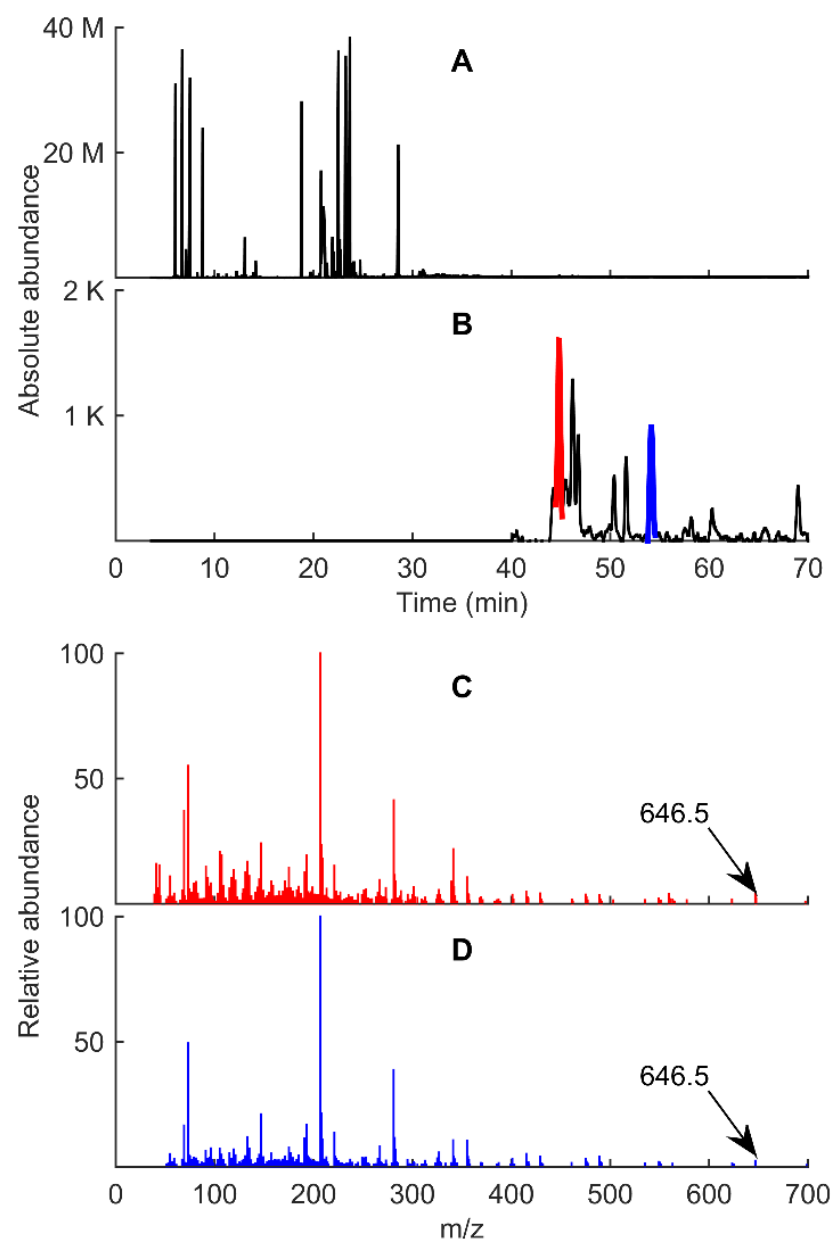

Figure 7. GC-MS analyses, displaying the total ion current (A) and the extracted ion chromatogram for $m / z>600$ (B) of a methylated oleoresin sample. Mass spectra for peaks at 44.9 $\min (\mathrm{C})$ and $54.1 \mathrm{~min}(\mathrm{D})$ are also depicted.

Biological Activity. The in vitro antiproliferative activities of abibalsamins (1, 2, 4-10) were evaluated against lung carcinoma (A549), colorectal adenocarcinoma (DLD-1), and normal skin 
fibroblast (WS1) human cell lines using a resazurin reduction test. ${ }^{44}$ The cytotoxicity results presented in Table 5 are expressed as the concentration inhibiting $50 \%$ of the cell growth $\left(\mathrm{IC}_{50}\right)$. Etoposide was used as a positive control with $\mathrm{IC}_{50}$ value 1.7 to $2.0 \mu \mathrm{M}$ for both cancer cell lines. Only abibalsamins B and $\mathrm{H}-\mathrm{J}$ exhibited moderate cytotoxic activity against A549 cancer cells, with $\mathrm{IC}_{50}$ values ranging between 6.7 and $10 \mu \mathrm{M}$. These results suggest that abibalsamins $\mathrm{B}$ and H-J could represent a novel chemical scaffold for the development of selective drugs against lung cancer.

Table 5. Cytotoxic Activity of Abibalsamins (1, 2, 4-10)

\begin{tabular}{|c|c|c|c|}
\hline \multirow{2}{*}{ abibalsamins } & \multicolumn{3}{|c|}{$\mathrm{IC}_{50}(\mu \mathrm{M})$} \\
\hline & A549 & DLD-1 & WS1 \\
\hline $\mathrm{A}(\mathbf{1})$ & $>10$ & $>10$ & $>10$ \\
\hline $\mathrm{B}(\mathbf{2})$ & $7.2 \pm 0.6$ & $>10$ & $>10$ \\
\hline $\mathrm{D}(4)$ & $>10$ & $>10$ & $>10$ \\
\hline $\mathrm{E}(\mathbf{5})$ & $>10$ & $>10$ & $>10$ \\
\hline$F(6)$ & $>10$ & $>10$ & $>10$ \\
\hline $\mathrm{G}(7)$ & $>10$ & $>10$ & $>10$ \\
\hline $\mathrm{H}(\mathbf{8})$ & $6.7 \pm 0.7$ & $>10$ & $>10$ \\
\hline I (9) & $9 \pm 1$ & $>10$ & $>10$ \\
\hline $\mathrm{J}(\mathbf{1 0})$ & $10 \pm 2$ & $>10$ & $>10$ \\
\hline etoposide ${ }^{b}$ & $1.7 \pm 0.2$ & $2.0 \pm 0.3$ & $>10$ \\
\hline
\end{tabular}

${ }^{b}$ Positive control.

In conclusion, eight tetraterpenoids, abibalsamins C-J (3-10), were isolated from A. balsamea oleoresin and characterized by means of 2D NMR and DFT calculations. Their relative configurations were tentatively determined by a qualitative comparison of some ROESY correlations with the mean calculated distances. Their absolute configurations were inferred from their biosynthetic pathway, along with a comparison of their experimental and calculated ECD spectra. The cytotoxic activities of these compounds were evaluated using two carcinogenic and 
one healthy cell lines. Abibalsamins B and $\mathrm{H}-\mathrm{J}$ exhibited moderate, but selective activity against A549 cancer cells.

\section{EXPERIMENTAL SECTION}

General Experimental Procedures. Optical rotations were measured on an Autopol IV polarimeter using a $10 \mathrm{~cm}$ cell at approximately $25^{\circ} \mathrm{C}$. IR spectra were recorded on a Fourier transform spectrometer (Perkin-Elmer Sperctrum One). A film of the sample was deposited on a $\mathrm{NaCl}$ window using a $\mathrm{CHCl}_{3}$ solution. The $1 \mathrm{D}$ and $2 \mathrm{D}$ NMR spectra $\left({ }^{1} \mathrm{H}-{ }^{1} \mathrm{H}\right.$ gCOSY, TOCSY, gHSQC, gHMBC and ROESY) were recorded on a Bruker Avance 400 spectrometer (400.13 MHz for ${ }^{1} \mathrm{H}$ and $100.61 \mathrm{MHz}$ for ${ }^{13} \mathrm{C}$ ) equipped with a $5 \mathrm{~mm}$ quadruple nuclear probe (QNP). All spectra were acquired in $\mathrm{CDCl}_{3}$ and chemical shifts were reported in ppm $(\delta)$ relative to TMS. For ROESY experiments, a gradient-enhanced pulse program was used with a continuous low-power pulse of $200 \mathrm{~ms}$ as a spin-lock pulse which is equivalent to a mixing time. The carrier frequency was placed at $3.5 \mathrm{ppm}$ with a spectral width of $2.7 \mathrm{KHz}$. ECD spectra were recorded with a Jasco J-815 spectrometer using MeOH solutions. HRESIMS data were obtained in the positive mode on an Applied Biosystems/MDS Sciex QSTAR XL QqTOF MS system. HPLC separations were performed on an Agilent 1100 series system with a $6.0 \times 250 \mathrm{~mm} \mathrm{C}_{18}$ reversed-phase column (Inertsil prep-ODS, $10 \mu \mathrm{m}$ of particle size) using $\mathrm{H}_{2} \mathrm{O}: \mathrm{CH}_{3} \mathrm{CN}$ as eluents, with $\mathrm{H}_{2} \mathrm{O}$ adjusted to $\mathrm{pH} 4$ with formic acid (HPLC grade) for improved separations. Chromatographic conditions were as follows: isocratic elution with $\mathrm{H}_{2} \mathrm{O} \mathrm{pH}$ 4: $\mathrm{CH}_{3} \mathrm{CN}$ (70-95\% $\mathrm{CH}_{3} \mathrm{CN}$ ) at a flow rate of $0.8 \mathrm{~mL} / \mathrm{min}$ and a column oven temperature at $25^{\circ} \mathrm{C}$. Preparative HPLC separations were carried out on a $20.0 \times 250 \mathrm{~mm} \mathrm{C}_{18}$ column (Inertsil prep-ODS, $10 \mu \mathrm{m}$ of particle size). GCMS analyses were performed on an Agilent mass spectrometer 5972 at $70 \mathrm{eV}$ 
coupled to an Agilent 7890C GC system with an Agilent PAL autosampler. The solvents were purchased from VWR (Ville Mont-Royal, Canada). TLC was performed on precoated silica gel 60 F254 aluminium sheets (250 $\mu$ m thickness) supplied by Silicycle (Ville de Québec, Canada). Silica gel 60 (neutral, 40-63 $\mu \mathrm{M}$ ), also supplied by Silicycle, was used for column chromatography. Solvent systems for TLC analyses were: a) hexanes-EtOAc (3:1), b) $\mathrm{CHCl}_{3}$ EtOAc (80:1 to 20:1), c) $\mathrm{CHCl}_{3}-\mathrm{MeOH}(40: 1)$ developing with $\mathrm{H}_{2} \mathrm{SO}_{4} 20 \%$ in $\mathrm{MeOH}$ followed by heating at $100{ }^{\circ} \mathrm{C}$.

Specimen Collection. Oleoresin of balsam fir (Abies balsamea L. Mill.) was collected by M. Marcel Pichette during the Summer of 2007 at Saguenay (Québec, Canada). One of the many trees harvested was sampled for formal identification by M. Patrick Nadeau (Département des Sciences Fondamentales, Université du Québec à Chicoutimi). A voucher specimen was deposited at the Louis-Marie Herbarium (Université Laval, QFA0579436).

Isolation of Compounds 3-10. A. balsamea oleoresin (500 g) were directly fractionated by silica gel column chromatography using hexanes:EtOAc $(100: 0 \rightarrow 93: 7)$ as eluant and finally washed with $\mathrm{MeOH}$. The fraction obtained with hexanes:EtOAc 93:7 was combined with the $\mathrm{MeOH}$ fraction and the resulting solution was evaporated under reduced pressure to give a brown gum (75 g). A portion of this extract (60 g) was further partionned on silica gel CC eluting with hexanes:EtOAc 3:1 (F1, $14 \mathrm{~g})$, hexanes:EtOAc 2:1 (F2, $19 \mathrm{~g})$, hexanes:EtOAc 1:1, and finally washed with $\mathrm{MeOH}(\mathrm{F} 3,21.5 \mathrm{~g})$. Subfraction F2 was fractionated on silica gel column with hexanes:EtOAc (3:1), generating five subfractions F2.1-F2.5. Repeated column chromatography of subfraction $\mathrm{F} 2.3$ on $\mathrm{C}_{18}$ reversed-phase with $\mathrm{H}_{2} \mathrm{O}: \mathrm{MeOH}$ (1:4 to $0: 1$ ) followed by purification 
employing preparative HPLC yielded compounds 3 (3.8 mg), 4 (4.8 mg), 5 (21.7 mg), 6 (36 mg), 7 (3.5 mg), 8 (6.3 mg), 9 (6.3 mg), and 10 (28.6 mg).

Abibalsamin $C$ (3): White amorphous solid; $[\alpha]^{20} \mathrm{D}-20\left(c 0.4, \mathrm{CHCl}_{3}\right)$; IR (film) $v_{\max } 3425$ (br), 2964 (s), $1706(\mathrm{~s}), 1378(\mathrm{~m}), 1261(\mathrm{~m}), 757(\mathrm{~m}) \mathrm{cm}^{-1} ;{ }^{1} \mathrm{H}$ and ${ }^{13} \mathrm{C}$ NMR, see Tables 1 and 2; HRESIMS $m / \mathrm{z} 619.4351[\mathrm{M}+\mathrm{H}]^{+}$(calcd for $\left.\mathrm{C}_{40} \mathrm{H}_{59} \mathrm{O}_{5}, 619.4357, \Delta=-1.0 \mathrm{ppm}\right)$.

Abibalsamin D (4): White amorphous solid; $[\alpha]^{20} \mathrm{D}-28\left(c 0.2, \mathrm{CHCl}_{3}\right)$; IR (film) $v_{\max } 3409$ (br), 2964 (s), 1707 (s), 1644 (m), 1450 (m), 1377 (m), 1261 (m), 801 (s), 757 (s) cm ${ }^{-1} ;{ }^{1} \mathrm{H}$ and ${ }^{13} \mathrm{C}$ NMR, see Tables 1 and 2; HRESIMS $m / z$ 619.4349 $[\mathrm{M}+\mathrm{H}]^{+}\left(\right.$calcd for $\mathrm{C}_{40} \mathrm{H}_{59} \mathrm{O}_{5}, 619.4357, \Delta=$ $-1.3 \mathrm{ppm})$.

Abibalsamin E (5): White amorphous solid; $[\alpha]^{20}-19\left(c\right.$ 1.1, $\left.\mathrm{CHCl}_{3}\right)$; IR (film) $v_{\max } 3420$ (br), 2952 (s), 1705 (s), 1639 (m), 1376 (m), 1287 (m), 757 (s) cm ${ }^{-1} ;{ }^{1} \mathrm{H}$ and ${ }^{13} \mathrm{C}$ NMR, see Tables 1 and 2; HRESIMS $m / z$ z $621.4508[\mathrm{M}+\mathrm{H}]^{+}$(calcd for $\left.\mathrm{C}_{40} \mathrm{H}_{61} \mathrm{O}_{5}, 621.4514, \Delta=-1.0 \mathrm{ppm}\right)$.

Abibalsamin $F(6)$ : White amorphous solid; $[\alpha]^{20}{ }_{\mathrm{D}}-131\left(c 1, \mathrm{CHCl}_{3}\right)$; IR (film) $v_{\max } 3417$ (br), 2964 (s), 1704 (s), 1460 (m), 1375 (m), 1295 (m), 1278 (m), 757 (s) cm ${ }^{-1} ;{ }^{1} \mathrm{H}$ and ${ }^{13} \mathrm{C}$ NMR, see Tables 1 and 2; HRESIMS $m / z$ 619.4346 $[\mathrm{M}+\mathrm{H}]^{+}\left(\right.$calcd for $\mathrm{C}_{40} \mathrm{H}_{59} \mathrm{O}_{5}, 619.4357, \Delta=-1.8$ ppm). 
Abibalsamin $G$ (7): White amorphous solid; $[\alpha]^{20}{ }_{\mathrm{D}}-142\left(c 0.4, \mathrm{CHCl}_{3}\right)$; IR (film) $v_{\max } 3424$ (br), 2964 (m), 1704 (s), 1638 (m), 1372 (w), 1293 (w) cm ${ }^{-1} ;{ }^{1} \mathrm{H}$ and ${ }^{13} \mathrm{C}$ NMR, see Tables 1 and 3; HRESIMS $m / z$ 619.4350 $[\mathrm{M}+\mathrm{H}]^{+}\left(\right.$calcd for $\left.\mathrm{C}_{40} \mathrm{H}_{59} \mathrm{O}_{5}, 619.4357, \Delta=-1.1 \mathrm{ppm}\right)$.

Abibalsamin $H(8)$ : White amorphous solid; $[\alpha]^{20}{ }_{\mathrm{D}}-118$ (c 1, $\mathrm{CHCl}_{3}$ ); IR (film) $v_{\max } 2949$ (s), 1708 (s), 1437 (m), 1374 (m), 1279 (m), 1192 (m), $756(\mathrm{~s}) \mathrm{cm}^{-1} ;{ }^{1} \mathrm{H}$ and ${ }^{13} \mathrm{C}$ NMR, see Tables 1 and 3; HRESIMS $m / z$ 633.4516 $[\mathrm{M}+\mathrm{H}]^{+}\left(\right.$calcd for $\left.\mathrm{C}_{41} \mathrm{H}_{61} \mathrm{O}_{5}, 633.4514, \Delta=0.3 \mathrm{ppm}\right)$.

Abibalsamin I (9): White amorphous solid; $[\alpha]^{20} \mathrm{D}-158\left(c 0.6, \mathrm{CHCl}_{3}\right)$; IR (film) $v_{\max } 3430$ (br), 2965 (m), 1705 (m), 1639 (m), 1375 (w), 1293 (w), 756 (m) $\mathrm{cm}^{-1} ;{ }^{1} \mathrm{H}$ and ${ }^{13} \mathrm{C}$ NMR, see Tables 1 and 3; HRESIMS $m / z$ 619.4349 $[\mathrm{M}+\mathrm{H}]^{+}$(calcd for $\mathrm{C}_{40} \mathrm{H}_{59} \mathrm{O}_{5}, 619.4357, \Delta=-1.3 \mathrm{ppm}$ ).

Abibalsamin J (10): White amorphous solid; $[\alpha]^{20}{ }_{\mathrm{D}}-164\left(c\right.$ 1, $\left.\mathrm{CHCl}_{3}\right)$; IR (film) $v_{\max } 2964$ (m), 1706 (s), 1372 (w), 1292 (w), 756 (w) $\mathrm{cm}^{-1}$; ${ }^{1} \mathrm{H}$ and ${ }^{13} \mathrm{C}$ NMR, see Tables 1 and 3; HRESIMS $m / z 619.4352[\mathrm{M}+\mathrm{H}]^{+}$(calcd for $\mathrm{C}_{40} \mathrm{H}_{59} \mathrm{O}_{5}, 619.4357, \Delta=-0.8 \mathrm{ppm}$ ).

GC-MS Analysis of the Oleoresin. Oleoresin (50 mg) was dissolved in $\mathrm{CH}_{2} \mathrm{Cl}_{2}(1 \mathrm{~mL})$ and methylated using diazomethane. ${ }^{45}$ The solution was analyzed by GC-MS, using a DB-5 column $(30 \mathrm{~m} \times 0.25 \mathrm{~mm} \times 0.25 \mu \mathrm{m})$ and helium as the carrier gas (flow $\left.1 \mathrm{~mL} \mathrm{~min}^{-1}\right)$. The injector temperature was maintained at $280{ }^{\circ} \mathrm{C}$. The injection volume was $2 \mu \mathrm{L}$ in a split ratio of 10:1. The GC temperature was kept at $60{ }^{\circ} \mathrm{C}$ for two min and raised at a rate of $10{ }^{\circ} \mathrm{C} / \mathrm{min}$ up to $325^{\circ} \mathrm{C}$ which was held constant for $60 \mathrm{~min}$. An electronic ionization of $70 \mathrm{eV}$ was used for MS detection. The data were recorded from $\mathrm{m} / \mathrm{z} 35$ to 750 . The temperatures at source and quadrupole were maintained at 230 and $150^{\circ} \mathrm{C}$, respectively. 
Computational Data. Conformers were generated for compounds 3, 5-7, and 9-10 using Spartan software. ${ }^{46}$ The force field MMFF94 was used with the Monte-Carlo algorithm. Geometries of the 100-200 most stable conformers $\left(\Delta \mathrm{E}<1 \mathrm{kcal} \mathrm{mol}^{-1}\right)$ were optimized using the Gaussian 09 software. ${ }^{47}$ DFT calculations were performed in the gas phase at the B3LYP/3-21G level of theory. Frequencies were also calculated to ensure that no imaginary value was present, confirming that all of the structures were local minima. This also led to the thermal free energies permitting the room temperature equilibrium populations to be calculated according to the Maxwell-Boltzmann distribution law. Excitation energy and rotatory strength in velocity were calculated for 40 transition states by TDDFT at B3LYP/3-21G//B3LYP/3-21G level in MeOH. The ECD spectra were then simulated by overlapping gaussian functions for each transitions according to:

$$
\Delta \varepsilon(E)=\frac{1}{2.297 \times 10^{-39} \sqrt{2 \pi \sigma}} \sum_{i} \Delta E_{i} R_{i} e^{-\left[\left(E-E_{i}\right) / 2 \sigma\right]^{2}}
$$

where $\sigma$ is the width of the band at $1 / e$ height $(0.20 \mathrm{eV})$ and $\Delta E_{i}$ and $R_{i}$ are the excitation energies and rotatory strengths for transition $i$, respectively.

Calculated distances from models were averaged such that a comparison with distances evaluated from ROESY spectra could be achieved. For this, the following equation was used:

$$
r_{\text {mean }}=\left(\sum_{i} p_{i} r_{i}^{-6}\right)^{-1 / 6}
$$

where $r_{i}$ is the distance measured from molecule $i$ and $p_{i}$ is the room temperature equilibrium proportion. 
Resazurin Assay for Cytotoxic Activity. Cytotoxicity was evaluated against lung carcinoma (A549), colon adenocarcinoma (DLD-1) and normal skin fibroblasts (WS1) using the resazurin reduction test as previously reported. ${ }^{44}$ Etoposide was used as a positive control.

\section{ASSOCIATED CONTENT}

\section{Supporting Information}

The ${ }^{1} \mathrm{H}$ and ${ }^{13} \mathrm{C}$ NMR, DEPT135, COSY, HSQC, HMBC, ROESY and HRESIMS spectra of abibalsamins (3-10), and computational data. This material is available free of charge via the Internet at http://pubs.acs.org.

\section{AUTHOR INFORMATION}

\section{Corresponding Author}

E-mail: andre.pichette@uqac.ca; Tel: +1 4185455011 ext. 5081; Fax: +1 4185455012

\section{Notes}

The authors declare no competing financial interest.

\section{ACKNOWLEDGMENTS}

This work was supported by the Fonds Québécois de Recherche Nature et Technologies (PhD

fellowship to S. L.). This research has been enabled by the use of computing resources provided 
by WestGrid and Compute Canada. We acknowledge Ms Catherine Dussault for the biological activity determination. We also thank M. Marcel Pichette for collecting the oleoresin.

\section{REFERENCES}

(1) Mabberley, D. J. Mabberley's Plant-Book: a Portable Dictionary of Plants, Their

Classification and Uses; 3rd ed.; Cambridge University Press: Cambridge, 2008.

(2) Takahashi, T. J. Pharm. Soc. Jpn 1938, 58, 888-901.

(3) Lavoie, S. Isolement et Caractérisation de Principes Actifs d'Abies balsamea et de Cornus canadensis. Ph.D., Université du Québec à Chicoutimi, Chicoutimi, Québec, Canada, 2015.

(4) Herrick, J. W.; Snow, D. R. Iroquois Medical Botany; Syracuse University Press: 1995.

(5) Chandler, R. F.; Freeman, L.; Hooper, S. N. J. Ethnopharmacol. 1979, 1, 49-68.

(6) Pichette, A.; Larouche, P. L.; Lebrun, M.; Legault, J. Phytother. Res. 2006, 20, 371-373.

(7) Bowman, J. M.; Braxton, M. S.; Churchill, M. A.; Hellie, J. D.; Starrett, S. J.; Causby, G. Y.; Ellis, D. J.; Ensley, S. D.; Maness, S. J.; Meyer, C. D.; Sellers, J. R.; Hua, Y.; Woosley, R. S.;

Butcher, D. J. Microchem. J. 1997, 56, 10-18.

(8) Legault, J.; Dahl, W.; Debiton, E.; Pichette, A.; Madelmont, J. C. Planta Med. 2003, 69, 402407.

(9) Ross, J.; Gagnon, H.; Girard, D.; Hachey, J. M. J. Essent. Oil Res. 1996, 8, 343-346.

(10) Zavarin, E.; Snajberk, K.; Critchfield, W. B. Phytochemistry 1977, 16, 770-772.

(11) Chung, J. L.; Snajberk, K.; Zavarin, E. Phytochemistry 1974, 13, 179-183.

(12) Zavarin, E.; Snajberk, K. Phytochemistry 1972, 11, 1407-1421.

(13) Smedman, L. Å.; Snajberk, K.; Zavarin, E.; Mon, T. R. Phytochemistry 1969, 8, 1471-1479.

(14) Zavarin, E.; Snajberk, K. Phytochemistry 1965, 4, 141-148.

(15) Caron, L.; Deslauriers, A.; Mshvildadze, V.; Pichette, A. Microchem. J. 2013, 110, 587-590.

(16) Manville, J. F. Can. J. Chem. 1975, 53, 1579-1585.

(17) Manville, J. F.; Tracey, A. S. Phytochemistry 1989, 28, 2681-2686.

(18) Manville, J. F. Can. J. Chem. 1976, 54, 2365-2371.

(19) Bowers, W. S.; Fales, H. M.; Thompson, M. J.; Uebel, E. C. Science 1966, 154, 1020-1021.

(20) Gray, P. S.; Mills, J. S. J. Chem. Soc. 1964, 5822-5825.

(21) Beri, R. M.; Lemon, H. W. Can. J. Chem. 1970, 48, 67-69. 
(22) Lavoie, S.; Gauthier, C.; Legault, J.; Mercier, S.; Mshvildadze, V.; Pichette, A. Beilstein J. Org. Chem. 2013, 9, 1333-1339.

(23) Lavoie, S.; Legault, J.; Gauthier, C.; Mshvildadze, V.; Mercier, S.; Pichette, A. Org. Lett. 2012, 14, 1504-1507.

(24) Little, C. H. A.; Strunz, G. M.; La France, R.; Bonga, J. M. Phytochemistry 1972, 11, 35353536.

(25) Li, Y.-L.; Zhang, S.-D.; Jin, H.-Z.; Tian, J.-M.; Shen, Y.-H.; Yang, X.-W.; Li, H.-L.; Zhang, W.-D. Tetrahedron 2012, 68, 7763-7767.

(26) Li, Y. L.; Gao, Y. X.; Yang, X. W.; Jin, H. Z.; Ye, J.; Simmons, L.; Wang, N.; Steinmetz, A.; Zhang, W. D. Phytochemistry 2012, 81, 159-164.

(27) Yang, X. W.; Li, S. M.; Shen, Y. H.; Zhang, W. D. Chem. Biodiversity 2008, 5, 56-81.

(28) Zhao, Q. Q.; Song, Q. Y.; Jiang, K.; Li, G. D.; Wei, W. J.; Li, Y.; Gao, K. Org. Lett. 2015, $17,2760-2763$.

(29) Abad, A.; Arno, M.; Peiro, M.; Zaragoza, R. J. Tetrahedron 1991, 47, 3829-3844.

(30) Whitesell, J. K.; Minton, M. A. J. Am. Chem. Soc. 1987, 109, 225-228.

(31) Wenkert, E.; Wovkulich, P. M.; Pelliccíari, R.; Ceccherelli, P. J. Org. Chem. 1977, 42, 1105-1107.

(32) Oikawa, H.; Tokiwano, T. Nat. Prod. Rep. 2004, 21, 321-352.

(33) Kim, H. J.; Choi, E. H.; Lee, I. S. Phytochemistry 2004, 65, 2545-2549.

(34) Smith, M.; March, J. March's Advanced Organic Chemistry: Reactions, Mechanisms, and Structure; Hoboken, N.J. : John Wiley \& Sons: Hoboken, N.J., 2007.

(35) Polavarapu, P. L. Chirality 2012, 24, 909-920.

(36) Leeflang, B. R.; Kroon-Batenburg, L. M. J. J. Biomol. NMR 1992, 2, 495-518.

(37) Cheng, Y.; Peng, C.; Zhang, H.; Liu, X. Helv. Chim. Acta 2010, 93, 565-572.

(38) Cuthbertson, J. D.; Godfrey, A. A.; Taylor, R. J. K. Org. Lett. 2011, 13, 3976-3979.

(39) Auclair, K.; Sutherland, A.; Kennedy, J.; Witter, D. J.; Van den Heever, J. P.; Hutchinson,

C. R.; Vederas, J. C. J. Am. Chem. Soc. 2000, 122, 11519-11520.

(40) Kakushima, M.; Das, J.; Reid, G. R. Can. J. Chem. 1979, 57, 3356-3358.

(41) Veselovsky, V. V.; Gybin, A. S.; Lozanova, A. V.; Moiseenkov, A. M.; Smit, W. A.; Caple, R. Tetrahedron Lett. 1988, 29, 175-178.

(42) Kelly, W. L. Nature 2011, 473, 35-36. 
(43) Kim, H. J.; Ruszczycky, M. W.; Choi, S. H.; Liu, Y. N.; Liu, H. W. Nature 2011, 473, 109112.

(44) Mshvildadze, V.; Legault, J.; Lavoie, S.; Gauthier, C.; Pichette, A. Phytochemistry 2007, 68, 2531-2536.

(45) Schlenk, H.; Gellerman, J. L. Anal. Chem. 1960, 32, 1412-1414.

(46) Spartan'10, Irvine, CA 92612 (USA).

(47) Frisch, M. J.; Trucks, G. W.; Schlegel, H. B.; Scuseria, G. E.; Robb, M. A.; Cheeseman, J. R.; Scalmani, G.; Barone, V.; Mennucci, B.; Petersson, G. A.; Nakatsuji, H.; Caricato, M.; Li, X.; Hratchian, H. P.; Izmaylov, A. F.; Bloino, J.; Zheng, G.; Sonnenberg, J. L.; Hada, M.; Ehara, M.; Toyota, K.; Fukuda, R.; Hasegawa, J.; Ishida, M.; Nakajima, T.; Honda, Y.; Kitao, O.; Nakai, H.; Vreven, T.; Jr., J. A. M.; Peralta, J. E.; Ogliaro, F.; Bearpark, M.; Heyd, J. J.; Brothers, E.; Kudin, K. N.; Staroverov, V. N.; Keith, T.; Kobayashi, R.; Normand, J.; Raghavachari, K.; Rendell, A.; Burant, J. C.; Iyengar, S. S.; Tomasi, J.; Cossi, M.; Rega, N.; Millam, J. M.; Klene, M.; Knox, J. E.; Cross, J. B.; Bakken, V.; Adamo, C.; Jaramillo, J.; Gomperts, R.; Stratmann, R. E.; Yazyev, O.; Austin, A. J.; Cammi, R.; Pomelli, C.; Ochterski, J. W.; Martin, R. L.; Morokuma, K.; Zakrzewski, V. G.; Voth, G. A.; Salvador, P.; Dannenberg, J. J.; Dapprich, S.; Daniels, A. D.; Farkas, O.; Foresman, J. B.; Ortiz, J. V.; Cioslowski, J.; Fox, D. J. Gaussian 09, Revision D.01, Wallingford CT (USA), 2013. 